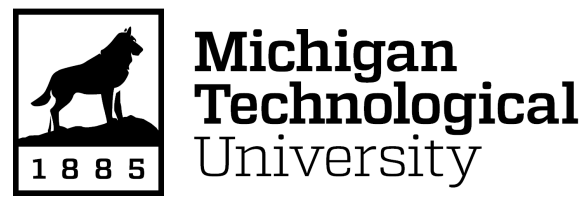

Michigan Technological University Digital Commons @ Michigan Tech

Dissertations, Master's Theses and Master's Reports

2020

\title{
RAIN GENERATED LAHARS PRIOR TO THE 2018 CATASTROPHIC ERUPTION OF FUEGO VOLCANO, GUATEMALA
}

Claudia Buondonno

Michigan Technological University, cbuondon@mtu.edu

Copyright 2020 Claudia Buondonno

\section{Recommended Citation}

Buondonno, Claudia, "RAIN GENERATED LAHARS PRIOR TO THE 2018 CATASTROPHIC ERUPTION OF FUEGO VOLCANO, GUATEMALA", Open Access Master's Thesis, Michigan Technological University, 2020. https://doi.org/10.37099/mtu.dc.etdr/1150

Follow this and additional works at: https://digitalcommons.mtu.edu/etdr

Part of the Environmental Indicators and Impact Assessment Commons, Geological Engineering Commons, Geology Commons, and the Volcanology Commons 


\section{RAIN GENERATED LAHARS PRIOR TO THE 2018 CATASTROPHIC ERUPTION}

OF FUEGO VOLCANO, GUATEMALA

By

Claudia Buondonno

\section{A THESIS}

Submitted in partial fulfillment of the requirements for the degree of MASTER OF SCIENCE

In Geology

MICHIGAN TECHNOLOGICAL UNIVERSITY

2020

(C) 2020 Claudia Buondonno 
This thesis has been approved in partial fulfillment of the requirements for the Degree of MASTER OF SCIENCE in Geology.

Department of Geological and Mining Engineering and Sciences

\author{
Thesis Co-Advisor: $\quad$ Dr. Rudiger Escobar Wolf \\ Thesis Co-Advisor: Dr. Paolo Frattini \\ Committee Member: Dr. Thomas Oommen \\ Committee Member: Dr. Simon Carn
}

Department Chair: Dr. John Gierke 


\section{Table of Contents}

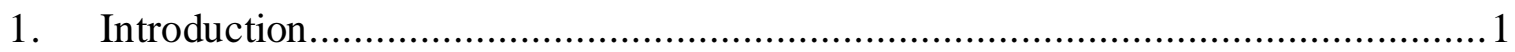

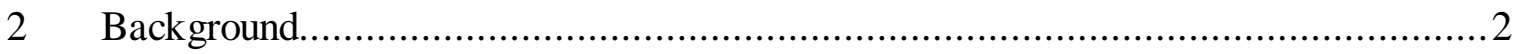

2.1 Central American Volcanic Arc .....................................................2

2.2 Fuego-Acatenango volcanic complex .........................................

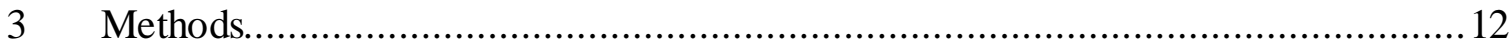

3.1 Lahars mapping by using satellite remote sensing................................... 12

3.2 Lahars mode ling with LAHARZ ..................................................... 15

3.3 Rainfall statistica lanaly sis of triggered lahars .................................... 19

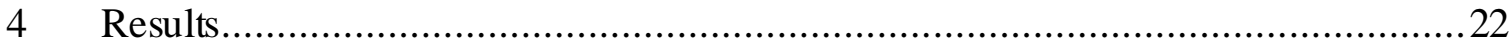

4.1 Satellite remote sensing .......................................................... 22

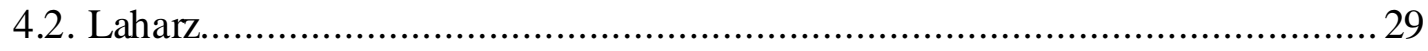

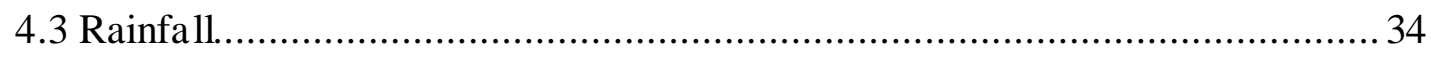

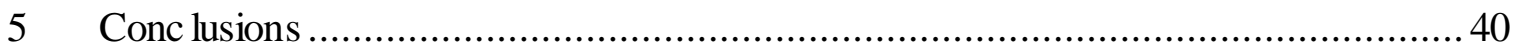

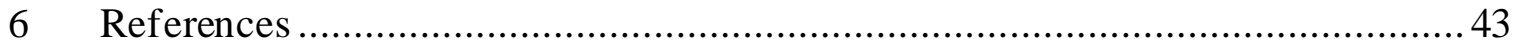

Appendix A................................................................. 47

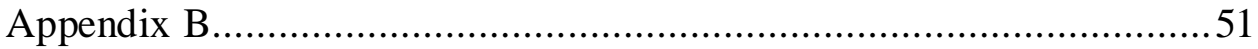




\section{List of figures}

Figure 2.1. Map showing the volcanoes of Central American Volcanic Arc (CAVA), as small gray triangles, and the Fuego volcano location with the larger white triangle. Also shown is the approximate subduction plate boundary. Volcano locations were taken from the Smithsonian Global Volcanism Program (GVP 2020)

Figure 2.2. Evolution of the Acatenango volcano and the Fuego-Acatenango volcanic complex (Basset, 1996). 5

Figure 2.3. Graph showing the occurrence of eruptions during the current activity episode, starting in May of 1999. Each vertical linebrown represents an eruption, and the thick black line show the eruption count through time. Figure by Rüdiger Escobar Wolf used with permission ..................................................... 8

Figure 2.4. Map showing the main lahar channels (barrancas) and nearby communities. Figure by Rüdiger Escobar Wolf used with permission.

Figure 4.1. Map showing the associated with deposition of material for different time periods between January 2017 andJanuary 2018.

Figure 4.2. Map showing the changes associated with deposition of material during the January to July 2018 time period, overlaid on the changes corresponding to the January 2017 to January 2018 period, as shown in figure 4.1.

Figure 4.3. Comparison between satellite based mapping of lahar deposits from the 2017 lahar activity (left panel), and LAHARZ simulated inundation areas for the Pantaleon channel and adjacent areas (right panel).

Figure 4.4. Lahar inundation areas based on satellite image mapping (left panel) compared with LAHARZ modeling with an input volume of $25149.67 \mathrm{~m} 3$ (right panel), for a stretch of the Ceniza channel.

Figure 4.5. Rainfall intensity and duration plots (blue circles) corresponding to the lahars reported in the INSIVUMEH database for rainfall recorded at different stations. Also included is the threshold (magenta line)for debris flows and landslides given by Guzzetti et al. (2008)

Figure 4.6. Histogram of time intervals between explosive eruptions and the occurrence of lahars at Fuego volcano. Data from Escobar-Wolf (2013) and INSIVUMEH (unpublished). 
Figure 6.1. Comparison between satellite based mapping of lahar deposits from the July 2017 lahar activity (left panel) and July 2018 lahar activity (right panel) in the Achiguate channel.

Figure 6.2. Comparison between satellite based mapping of lahar deposits from the July 2017 lahar activity (left panel) and October 2017 lahar activity (right panel) in the Ceniza channel.

Figure 6.3. . Comparison between satellite based mapping of lahar deposits from the October 2017 lahar activity (left panel) and July 2018 lahar activity (right panel) in the Taniluya channel

Figure 6.4. Comparison between satellite based mapping of lahar deposits from the January 2018 lahar activity (left panel) and July 2018 lahar activity (right panel) in the Ceniza channel.

Figure 6.5. Comparison between satellite based mapping of lahar deposits from the January 2018 lahar activity (left panel) and July 2018 lahar activity (right panel) in the Pantaleon channel.

Figure 6.6. Comparison between satellite based mapping of lahar deposits from the July 2017 lahar activity (left panel) and October 2017 lahar activity (right panel) in the Pantaleon channel.

Figure 6.7. Comparison between satellite based mapping of lahar deposits from the January 2018 lahar activity (left panel) and July 2018 lahar activity (right panel) in the Pantaleon channel

Figure 6.8. Comparison between satellite based mapping of lahar deposits from the July 2017 lahar activity (left panel) and October 2017 lahar activity (right panel) in the Pantaleon channel. 


\section{List of tables}

Table 1 - Area and volume of each polygon visually mapped in the January 2017 - July

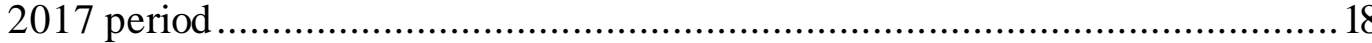

Table 2 - Area and volume of each polygon visually mapped in the July 2017 - October

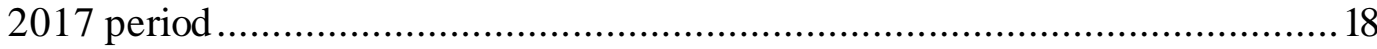

Table 3 - Lahars and paroxysms occurred between 2016 and 2018..........................................21

Table 4. Basic acquisition characteristics of the PlanetScope images used in the study...22 


\section{Definitions}

Barranca: a Spanish wordfor a deep ravine or a steep cliff.

International Space Station (ISS) Orbit: International Space Station(ISS) orbits at a $51.6^{\circ}$ inclination at approximately $400 \mathrm{~km}$ altitude. Planet deploys satellites from the ISS, each having a similar orbit.

Lahar: a violent type of mudflow or debris flow composed of a slurry of pyroclastic material, rocky debris and water. The material flows down from a volcano, typically along a river valley.

LAHARZ: GIS programs for automated mapping of lahar-inundation hazard zones.

Near-Infrared (NIR): Near Infrared is a region of the electromagnetic spectrum.

PlanetScope: The first three generations of Planet's optical systems are referred to as PlanetScope 0, PlanetScope 1, and PlanetScope 2.

Paroxysmal activity: An axplosive volcanic activity resulting in lava and ash being ejected.

Rainfall intensity: the ratio of the total amount of rain (rainfall depth) falling during a given period to the duration of the period It is expressed in depth units per unit time, usually as mm per hour $(\mathrm{mm} / \mathrm{h})$.

RapidEye: RapidEye refers to the five-satellite constellation in operation since 2009.

Scene: A single image captured by a PlanetScope satellite.

Sun Synchronous Orbit (SSO): A geocentric orbit that combines altitude and inclination in such a way that the satellite passes over any given point of the planet's surface at the same local solar time. 


\section{List of abbreviations}

Central American Volcanic Arc

(CAVA)

Digital Elevation Model

(DEM)

Geographical Information System

(GIS)

Guatemalan Government Coordination Agency for Disasters Reduction (CONRED)

Middle American Trench

(MAT)

National Institute of Seismology, Volcanology, Meteorology, and Hydrology (INSIVUMEH)

Near-Infrared

(NIR)

Normalized Vegetation Index

(NDVI)

International Space Station

(ISS)

PlanetLabs

(PL)

PlanetScope

(PS)

Sun Synchronous Orbit

(SSO)

Volcanic Explosivity Index

(VEI) 


\begin{abstract}
Fuego volcano is one of the most active and hazardous volcanoes in the world. It is located in the northern part of the Central American Volcanic Arc in Guatemala and its activity can be characterized by longterm, low-level background activity, and sporadic larger explosive eruptions. Its historical observations of eruptions date back to 1531, but it has been erupting vigorously since 2002 with major activity throughout 2018 , producing three main eruptions inFebruary, June and November.
\end{abstract}

Its almost persistent activity generates major ashfalls, pyroclastic flows, lava flows; when heavy rains mobilize its deposits, they can form damaging lahars. Phenomena, like pyroclastic flows and lahars, have a very high potential to be hazardous and highly lethal, considering that Fuego is also surrounded by a series of small villages and cities like Escuintla, Masagua or San Miguel Los Lotes.

The sub-plinia $n$ eruption that happened between the $3^{\text {rd }}$ and $5^{\text {th }}$ of June 2018 was the deadliest event in the recent history of the volcano. It produced around 20 million $\mathrm{m}^{3}$ airfalll tephra volumes, and about 50 million $\mathrm{m}^{3}$ of pyroclastic flow deposits. This event triggered major lahars descending multiple channels - locally called barrancas - that surround the volcano edifice. More than 12 thousand people of the communities of Sangre de Cristo, Finca Palo Verde and Panimache have been evacuated to escape from the violent eruption.

This project is aimed to study and analyze the volcano changes throughout 2017, i.e., the year right before the June $3^{\text {rd }}$ disruptive event. Although the June $3^{\text {rd }} 2018$ eruption had the largest and most tragic impact, mainly caused by the generation of pyroclastic density currents, this work shows that significant lahar activity and sediment mobilization occurred already in 2017 , associated to explosive eruptive activity that was frequent that year. 
Geographical, seasonal and infrastructural restrictions make ground-based monitoring not always practical. Therefore satellite-based remote sensing methods can particularly be beneficial for volcano monitoring.

High-resolution images acquired from a constellation of over 130 cubesats operated by Planet Labs Inc were used for this study. Through the satellite remote sensing data, lahar zones were detected in order to assess hazards caused by volcanic eruptions. Because the approach of automated methods was not successful in delineating the deposits in the barrancas and in the proximal areas, the lahars were visually mapped. This manual interpretation technique allowed to achieve high accuracy for hazard detection and monitoring.

Then, areas of lahars inundation were simulated and mapped using LAHARZ, a Geographical Information System (GIS) code created by the United States Geological Survey. This tool is used to produce hazard maps and evacuation solutions in a short time frame. The detected and simulated lahars zones were compared and verified. A statistical rainfall analysis was performed to see how the rainfall intensity can affect the triggering of the lahars.

The monitoring, mapping and the study of past events could assist volcanic hazard mitigation efforts in Guatemala and other active volcanoes in the world, enabling volcanologists and local governments to predict lahar and minimize the loss of human life and property. 


\section{Introduction}

Fuego is one of Central America's most active volcanoes, located in the central part of the Guatemalan Volcanic Arc. Since 2002 ithas been erupting vigorously, mainly having a background activity; however, during 2018 itwas characterized by intense paroxysm with three major events in February, June and November. These events generated lava flows, pyroclastic density currents and tephra fall. Posterior remobilization of pyroclastic flow material by stream erosion in the confined barrancas leads to lahar generation, either by normal rainfall, or by extreme rainfall events.

Periods of rain, trigger debris flows by mobilizing fresh pyroclastic debris in the steep barrancas of the edifice often producing lahars which, in turn, grade downslope into stream deposits. After periods of volcanism, channels are choked with sediment. As a result, floods spill onto adjacent interfluves, and periodically river channels change their course.

Lahars pose the biggest threat to people living or recreating along the channels that drain Fuego, therefore analyzing historical events may help to assess the future hazard potential at Fuego.

Since ground-based techniques may not be the best option during and after eruptive activity, satellite images provide an opportunity for a new and detailed perspective. The PlanetScope (PS) data represent a significant tool for volcano monitoring and rapid deposits mapping, which can be performed using change detection methods or visual mapping. Even though the visual mapping has the disadvantage of the speed of reproduction, the manual interpretation technique allows for the achievement of high accuracy for hazard detection and monitoring. Satellite-based remote sensing methods combined with computer-simulated models can be particularly beneficial to generate volcanic hazard area maps and assess hazards caused by volcanic eruptions. 


\section{Background}

\subsection{Central American Volcanic Arc}

Fuego Volcano $\left(14.48^{\circ} \mathrm{N}, 90.88^{\circ} \mathrm{W}\right)$ is a $3800 \mathrm{~m}$ stratovolcano located in Guatemala; it forms part of the north-south trending Fuego-Acatenango volcanic complex, that is perpendicular to the Central American Volcanic Arc (CAVA), see Figure 2.1.

The Central American Volcanic Arc runs parallel to the Middle American Trench (MAT) from the Mexico-Guatemalan border to central Costa Rica, where itis followed by a gap in volcanic activity from central Costa Rica to Panama (Gazel et al., 2011)

The volcanism of this active margin is the result of the subduction of the Cocos plate under the Caribbean plate.

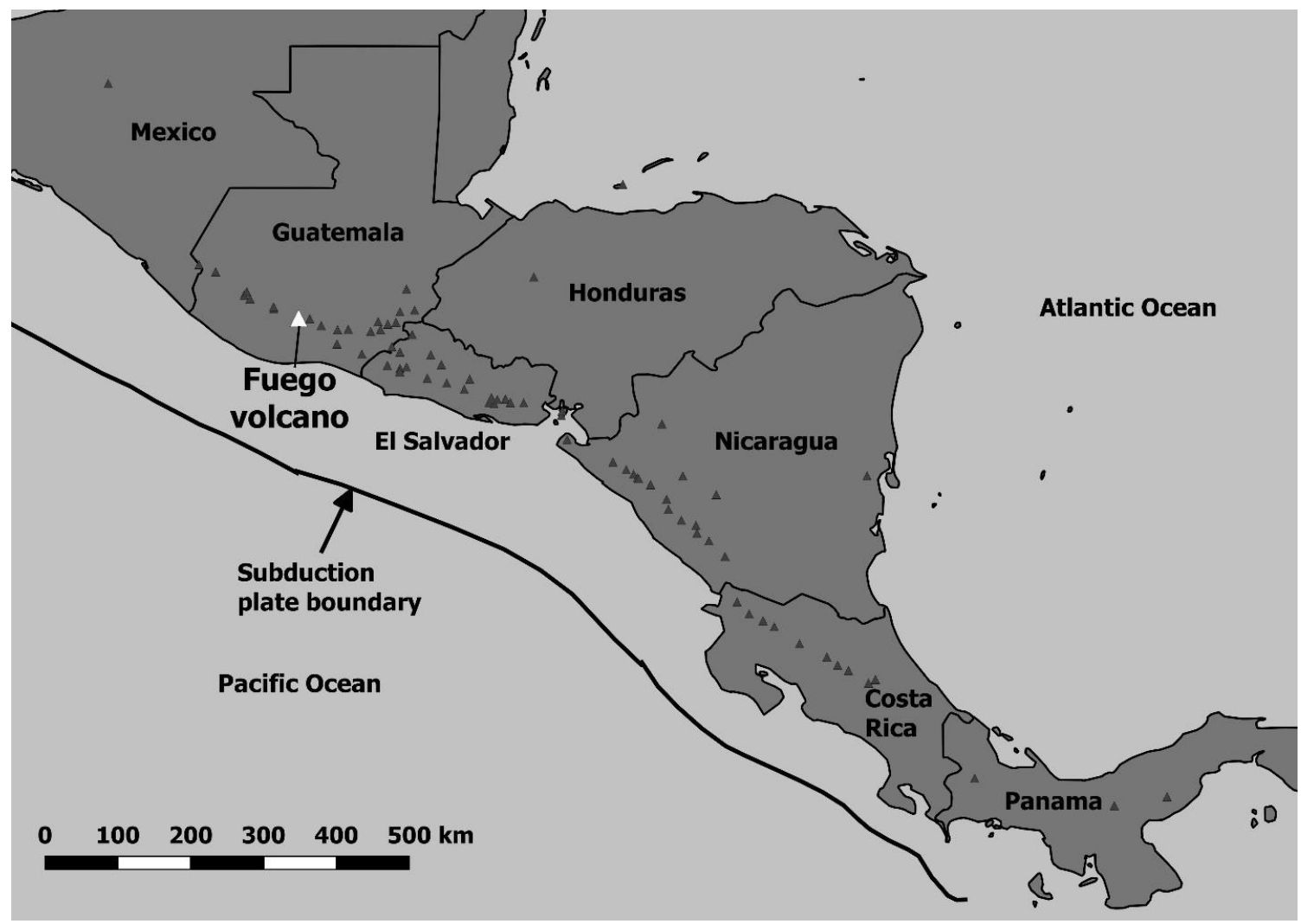

Figure 2.1. Map showing the volcanoes of Central American Volcanic Arc (CAVA), as small gray triangles, and the Fuego volcano location with the larger white triangle. Also 
shown is the approximate subduction plate boundary. Volcano locations were taken from the Smithsonian Global Volcanism Program (GVP2020).

The Cocos-Caribbean plate convergence that gives rise to the highly active and closely spaced Central American volcanic front is bounded by tectonically complex areas that obscure the triple junctions required by simpleplate tectonic theory. To the northwest, a zone of strike-slip faults cutting across Guatemala separates the Caribbean and North American plates. However, the curvature of the faults is opposite what would be expected from the North American-Caribbean pole of rotation. Volcanism ceases as the strike-slip fault zone disappears near the volcanic front at the Mexico-Guatemala border. At the southeast end of the Central American volcanic front, the subduction of the Cocos ridge coincides with the substantial volcanic gap between central Costa Rica and western Panama (Carr et al., 2007).

The convergence rate between the Cocos and Caribbean plates increases to ward the southeast from $\sim 60 \mathrm{~mm} / \mathrm{yr}$ off southern Guatemala to $\sim 90 \mathrm{~mm} / \mathrm{yr}$ off southern Costa Rica (DeMets, 2001).

Crustal thickness ranges from $48 \mathrm{~km}$ in northwestern Guatemala to $32 \mathrm{~km}$ in Nicaragua (Carr et al., 1990). South-eastern Guatemala has an intermediate crustal thickness ranges of about $40 \mathrm{~km}$ (Carr et al., 1990). Whereas the Cocos plate subducts beneath Nicaragua at the steep angle of $65-84^{\circ}$ (Carr et al.,1990; Protti et al., 1995), the angle of subduction lies closer to $40^{\circ}$ in Guatemala (Cameron et al., 2002).

This area has been studied for its conflicting geochemical characteristics that depend on important variations in the arc crust's thickness, the subduction angle, and the style of fracturing in the subducted plate. 
The arc is divided into eight structural segments, three of which (the northwestern, central, and southeastern) are located in Guatemala (Cameron et al., 2002). Each segment has variable geological and geophysical characteristics and are separated by right steps of $10 \mathrm{~km}$ to $40 \mathrm{~km}$ that Bukart and Self (1985) attribute to upper plate structures related to the strike-slip boundary crossing Guatemala that separates the North American and Caribbean plates.

In recent geologic time, the central Guatemalan volcanic lineament has been the most active volcanic segment in Central America (Stoiber and Carr, 1973) and Fuego, about 45 $\mathrm{km}$ west-southwest of Guatemala City, results the most active volcano in Central America.

\subsection{Fuego-Acatenango volcanic complex}

Fuego volcano is situated near the linear extension of the eastern Motagua fault, which represents the continental extension of the Caribbean-North American plate boundary through Guatemala.

The Motagua fault is a strike-slip fault which is part of a complex zone consisting of four major subparallel arcuate fault zones that trend in a general east-west direction across Guatemala and northern Honduras (Espinosa 1976). The eastern portion of the fault is approximately linear and parallel to the local direction of relative plate motion, but, at approximately $89.5^{\circ} \mathrm{N}$ of longitude, the fault changes in direction and it curves concave to the north. This is, probably due to the complex stress field associated with the Caribbean-Cocos-North American triple junction zone, as Spence and Person (1976) described. 
The Fuego-Acatenango massif comprises a complex of five composite volcanoes, Ancient Acatenango, Yepocapa, Pico Mayor de Acatenango, Meseta, and Fuego, along a north-south trend, that is perpendicular to that of Central American arc in Guatemala. This massive volcano complex towers more than 3500 meters above the Pacific coastal plain to the south and $2000 \mathrm{~m}$ above the Guatemalan Highlands to the north (Vallance et al., 2001).

Although many of the centers have been active contemporaneously, with the trend that stretches back more than 200,000 years, there is a general sequence of younger volcanism from north to south (Vallance et al., 2001). This, that means Ancient Acatenango as the oldest, and Fuego as the youngest.

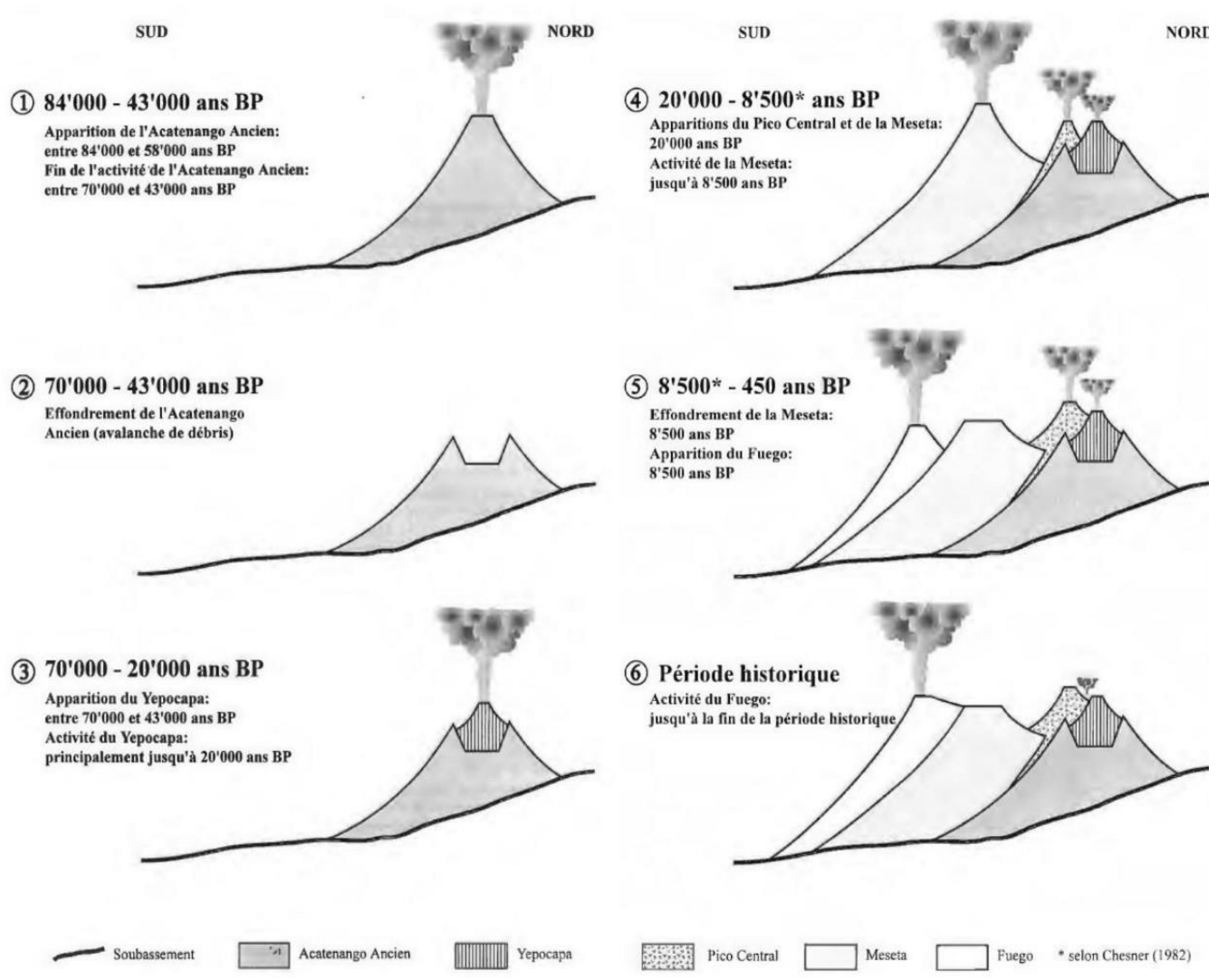

Figure 2.2. Evolution of the Acatenango volcano and the Fuego-Acatenango volcanic complex (Basset, 1996). 
The oldest age dates within the Fuego-Acatenango volcanic complex are about 230,000 years (Chesner and Halsor, 2006, Waite et al., 2013), although, according to Basset (1996) and the pre-historical evolution that he proposed, the main growth period of the Acatenango volcano began between 84,000 and 58,000 years ago. Its activity culminated sometime before 43,000 years ago, with a $1.2 \mathrm{~km} 3$ debris avalanche, which today is identified near La Democracia. The debris travelled $40 \mathrm{~km}$ along the southwestern flank. This collapse has brought to a $2 \mathrm{~km}$ in diameter horseshoe-shaped caldera open to the southwest and the loss of about $600 \mathrm{~m}$ of altitude (from $4000 \mathrm{~m}$ to $\sim 3300 \mathrm{~m}$ ) of the volcanic edifice. Between 70,000 and 43,000 years before present (BP), the activity continued into the Ancient Acatenango, with the growth of the Yepocapa cone, which was active mostly from 20,000 years BP.

Around 20,000 years ago even the Pico Mayor de Acatenango and La Meseta appeared, but around 8,500years BP La Meseta cone collapsed generating a $9 \mathrm{~km}^{3}$ debris avalanche that now underlies more than $300 \mathrm{~km}^{2}$ of the Pacific coastal plain south of Escuintla. Extrapolating the historical volume rate of eruption suggests that the entire edifice of Fuego volcano could have been constructed in 8,500years (Vallance et al., 2001); thus, it's possible to see how in the Fuego-Acatenango massif the activity migrated southwards, from Yepocapa to the Fuego, one of the country's youngest and most active volcanoes; the evolution of the volcanic complex is visible in the Figure 2.2.

Fuego has had at least 60 historical subplinian eruptions and experienced several long periods (from months to years), of low-level Strombolian activity. Its activity has been documented inhistorical records dating back to the early 16th century, including several large explosive eruptions. However, it is more studied and monitored since the last most recent and most voluminous $(0.1 \mathrm{~km} 3)$ subplinian eruption of 1974 ; this last episode was characterized by a Volcanic Explosivity Index (VEI) of 4, that produced ash fall, pyroclastic flows and lahars causing panic in the local population (Rose et al., 1978). 
After the 1974 major eruption, most recently Fuego entered a new episode of activity and it has been erupting vigorously since 2002. These eruptions have resulted in major ashfalls, pyroclastic flows, lava flows, and damaging lahars. Large explosions with hundreds of fatalities occurred during 3-5 June 2018; after a brief pause, significant activity resumed and continued during April-September 2019.

The activity at Fuego can be broadly divided into two main levels:

1. A persistent low-level background activity, persisting over the whole eruptive episode, that alternates between effusive lava flows and small size transient explosive eruptions.

This normal background state produces small gas and tephra clouds, ballistic projectiles, and small rockfalls and avalanches during the low-level explosive activity. Short lava flows near the vent and persistent rockfalls and avalanches of small volume occur during the effusive activity as well.

2. Sporadic above background-level explosive eruptions of larger size, that produce high amounts of air-fall tephra, ballistic projectiles, pyroclastic density currents and surges, and lava flows. Some of these events can trigger crises that involve the evacuation of people from the nearby communities. 


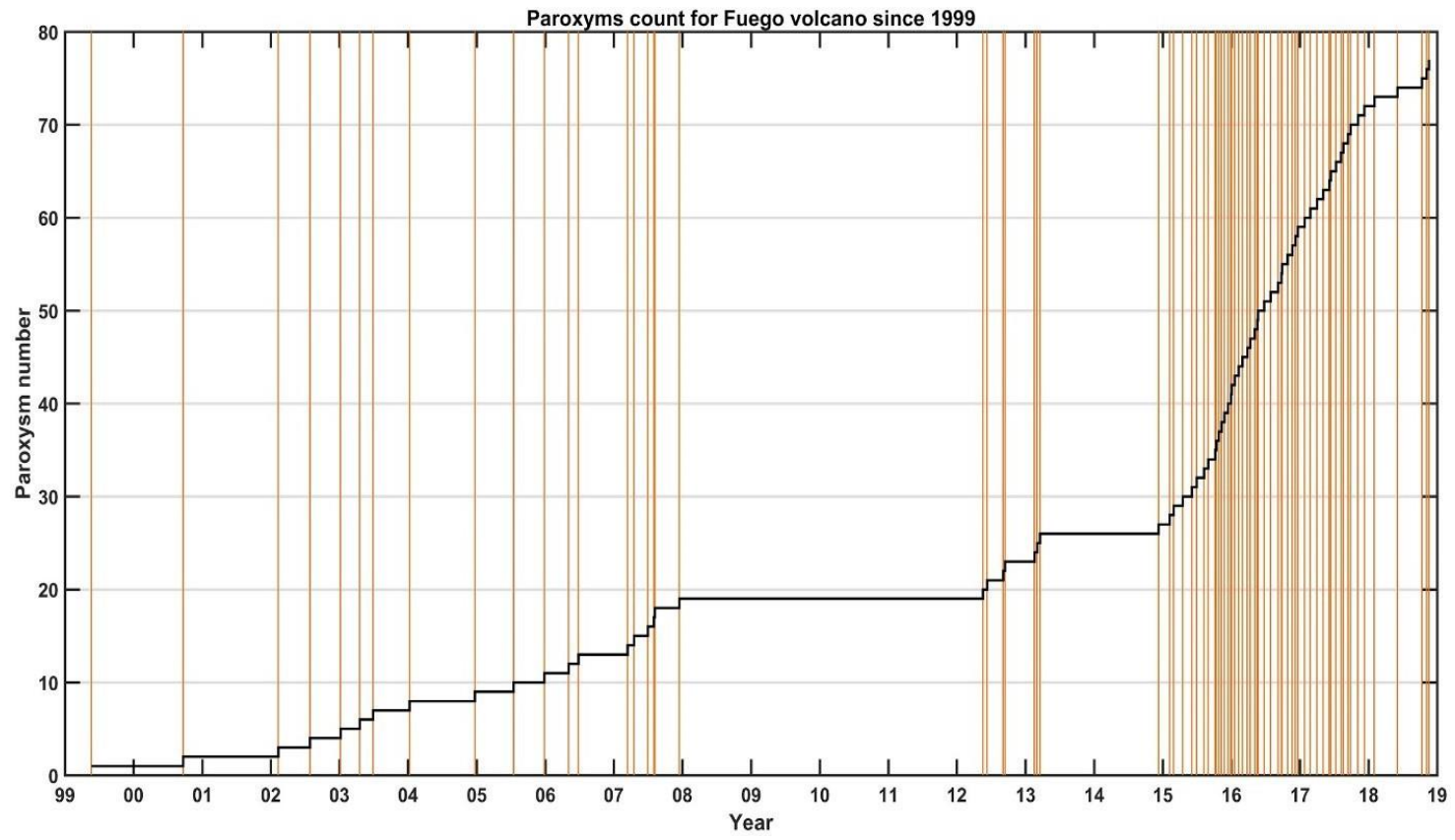

Figure 2.3. Graph showing the occurrence of eruptions during the current activity episode, starting in May of 1999. Each vertical line brown represents an eruption, and the thick black line show the eruption count through time. Figure by Rüdiger Escobar Wolf used with permission.

In the Figure 2.3 it's possible to see the 77 paroxysms that have happened since May 1999 with a recurrence highly variable through time but with a marked increase of events since 2015 .

The average typical paroxysm produces on the order of $106 \mathrm{~m} 3$ of material (mainly pyroclasts), but the larger events (e.g. May 1999, June 2003, Sep. 2012) are at least one order of magnitude larger. The June 3rd 2018 event was presumably close to two orders of magnitude larger.

This recent activity ischaracterized by frequent, paroxysmal short duration eruptions (i.e. 24-48 h), ash fall plume which can reach up to $10 \mathrm{~km}$ height (Vallance et al. 2001), and lava and pyroclastic flows. 
Therefore, activity ranges from ash-rich explosions to blocky lava flows to brief paroxysmal eruptions (VEI 2-3), accompanied by increased strombolian explosions and lava production. This activity lasts for days to weeks and occurs approximately annually (Lyons et al., 2010; Smithsonian Institution, 2019).

This almost continuous activity has been interpreted as an open vent condition, indicating that the vertical conduit, which has been the main vent in nearly all historic activity of Fuego, does not get constricted or plugged (Lyons et al., 2010).

Seismicity, like most other volcanoes, accompanies open vent activity. This includes harmonic and nonharmonic tremor, explosion earthquakes, long-period (LP) earthquakes, and very-long period (VLP) earthquakes (Lyons et al., 2010; Waite and Lyons, 2009). Given the high frequency of events at Fuego, seismic activity is also generally concentrated in intense earthquake swarms (Yuan et al., 1984) and is related to magma migrating upwards towards the eruptive vent through a system of dikes (Rose et al., 1978; Martin and Rose, 1981).

In general, the bulk magma composition ranges from high-Albasalt to basaltic andesite, but sampling of the flanks of Fuego has shown that older undated lavas are more andesitic than the historic materials (Martin and Rose, 1981).

Materials erupted since 1932 have been slightly but progressively more mafic, and there is also considerable variation in composition within each eruption episode. This might suggest that the variability is due to: magma differentiation along the vertical conduit (Ruelle, 1978), magma differentiation into the magmatic chamber (Chesner \& Rose, 1984), and mixing of different magmas (Roggensack, 2001; Berlo et al., 2012) both in the vertical conduit and in the magma chamber. Magmas mixing can trigger eruptions (Berlo et al., 2012) and increase the VEI of the eruptions (Mari, 2015). 
Phenomena, like pyroclastic flows and lahars, have a very high potential to be hazardous and highly lethal, considering that Fuego is also surrounded by populated cities such as Escuintla (population more than 110000 situated about $20 \mathrm{~km}$ south), Antigua Guatemala (approximately 34000 people; $15 \mathrm{~km}$ southwest), Chimaltenango (43 000 people, about $40 \mathrm{~km}$ north) and Guatemala City (population 2.1 million; $40 \mathrm{~km}$ southwest).

The relatively high-altitude of Fuego, that range from 1000 masl at the toe to 3760 masl at the top, moderates average temperatures but, due to its tropical position, the volcano site is still characterized by torrential seasonal rains.

Indeed, Guatemala is distinguished by a dry season, which extends from November to April, and a rainy season, which extends from May to October, coinciding with tropical storms and hurricane season in the western Atlantic Ocean and Caribbean Sea. Due to its location in the tropical Convergence Zone, Guatemala is commonly affected by cyclones like the tropical storm Stan (October 2005) and Agatha (May - June 2010).

Rainfall, especially after pyroclastic flow producing eruptions, commonly triggers lahars. This means that, during the rainy season, lahars can recur daily.

This causes the lahars to transport very large amounts of volcanic material from the steeper upper and medial sections of the cone, to the lower and flatter distal cone reaches and beyond; and itcan cause also erosion on prior volcanic deposits, especially on pyroclastic flow deposits emplaced during the current eruptive episode.

This effect can be amplified also by the anomalous extreme rainfall events that trigger land slides and debris flows on steeps slopes on Fuego volcano and other high slope terrains in the region. These events can cause extensive sedimentation and deposition of laharic material downstream. 
Flow (lava and pyroclastic) deposits are mostly restricted to the channels that drain the volcanic edifice, i.e. the Barrancas, but pyroclastic flow deposits can also overflow the channel margins, inundating the adjacent interfluvia 1 terrain, and causing the channel's avulsion. The mechanisms involved in the generation of the pyroclastic flows include the collapse of lava flow fronts, and other hot material located on unstable slopes at the summit region.

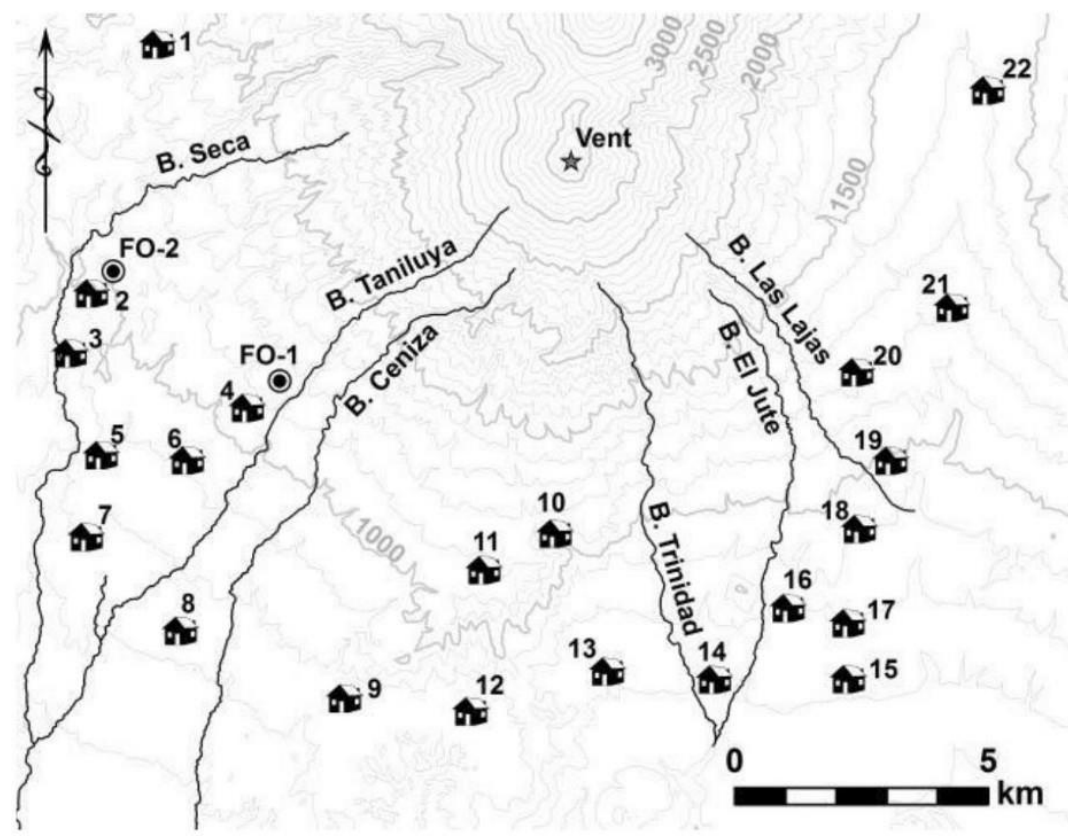

Figure 2.4. Map showing the main lahar channels (barrancas) and nearby communities. Figure by Rüdiger Escobar Wolf used with permission.

Fuego is drained by multiple drainages, locally known as "barrancas", seven of which usually receive the products of the volcano activity: Seca, Taniluya, Ceniza, Trinidad, El Jute, Las Lajas, and Honda (Figure 2.4). The influx of pyroclastic density currents material deposited in Barracas Las Lajas, El Jute, Ceniza and Santa Teresa after the June 3rd eruption, caused lahars descending the Pantaleón, Mineral, and other drainages, leading to the evacuations of the communities of Sangre de Cristo, Finca Palo Verde, Panimache and others. 


\section{Methods}

\subsection{Lahars mapping by using satellite remote sensing}

The main observation of volcano activity, eruption monitoring, and hazard evaluation and forecasting are undertaken by two important Guatemalan institutes; the National Institute of Seismology, Volcanology, Meteorology and Hydrology (INSIVUMEH) and the National Institute for Disaster Reduction (CONRED). The CONRED deals with disaster reduction strategies and hazard evacuation plans, partly in response to the information received from INSIVUMEH, which instead provides the main observation and forecasting capability through seismic monitoring and ground observatories at the major volcanoes and issues daily activity bulletins.

However, ground monitoring is not always effective because of geographical, seasonal or infrastructural restrictions, whereas satellites monitoring does not have the same limitations and can be used as a tool for improving early warning and forecasting of the activity of Fuego (Webley et al., 2008, Aldeghi et al., 2019). The use of remote sensing for mapping and monitoring natural hazards has diversified in recent years owing to an increase in data availability and technological advances in their interpretation (Joyce et al., 2009). Because remoteness or difficultfield conditions of ten limit the ability to collect field data, the use of satellite-based remote sensing methods is particularly beneficial for volcano monitoring indeveloping country regions and remoteareas.

Satellite remote sensing (or Earth observation, EO) has proved to be a multi-disc iplinary field with constant growth and improvement, concurrent with technological advances in satellite sensors (Dean et al., 2002; Herold et al., 2016; Pieri \& Abrams, 2004; M.

Ramsey \& Dehn, 2004; Thomas \& Watson, 2009). 
Planet, an aerospace company, builds and operates the largest constellation of imaging satellites: PlanetScope (130 + satellites), SkySats (13 satellites) and RapidEye (5 satellites) Earth-imaging constellations.

The company operates with more than 130 PlanetScope(PS), also named CubeSat or "Dove", each 10x10x30 cm sized. Its constellation has a collection capacity of $346 \mathrm{M}$ $\mathrm{km} 2 /$ day, which means that they are able to image the entire Earth every day at two different orbits: International Space Station (ISS) and Sun Synchronous Orbits (SSO).

Each Dove carries a telescope and 6600×4400-pixe 1 CCD array, which acquires both visible (red-green-blue or RGB) and near-infrared (NIR) PS data with 12-bit radiometric resolution. T; the "Analytic" data products were chosen between the several PS data products with different processing levels available; which are 16-bit calibrated and orthorectified data with a positional accuracy of better than $10 \mathrm{~m}$ (Aldeghi et al., 2019).

Fuego volcano produced a large number of lahars after the catastrophic June $3^{\text {rd }} 2018$ eruption, but extensive lahar activity had been common since the current cycle of activity began in 1999, and more recently had experienced a significant increase after large paroxysmal eruptions in the 2015 - 2017 period, particularly the large May 5 - 72017 eruption. This is the reason why this study was focused on the analysis of changes that have occurred during 2017 , before the 2018 events.

Through the Planet Explorer interface, the PlanetScope imagery products were downloaded, identifying the best images between January of 2017 and June of 2018 that showed significant changes through the barrancas in terms of new lahars deposits. They were also selected base on low cloud cover and high clarity.

First, a visual inspection of each image was performed, selecting suitable RGB color stretching values in order to highlight volcanic deposits and to identify and map changes 
due to the generation of lahars and pyroclastic flows deposits and their accumulation along the flanks of the volcano.

In the areas affected by changes in sediment coverage, a change detection strategy based on the Normalized Difference Vegetation Index (NDVI) changes were applied.

Indeed, the NDVI is used to determine the extent of vegetation cover in a pixel, since vegetation reflects strongly in the near-infrared (TM band 4, 0.76-0.90 $\mu \mathrm{m}$ ) and weakly in the visible red portion of the spectrum (TM band 3, 0.6-0.69 $\mu \mathrm{m}$ ), the band 4/band 3 ratio is sensitive to changes in vegetation health and cover, detecting even small differences in the spectral reflectance of rocks and vegetation.

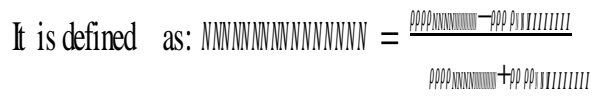

The NDVI values obtained in the pre-changes images were subtracted from the NDVI values of the post-changes images, with the difference between these values reflecting the impacts of the deposition of new volcanic material or the remobilization of old deposits. Changes in NDVI from positive to negative values would indicate areas where the vegetation decreased or new areas of impact where the vegetation is been removed and/or partially buried, e.g. in the areas affected by lahars.

A visual comparison between NDVI change and manual delineation mapping of deposits showed that the NDVI difference has some limitations, especially in areas that were originally non-vegetated, like the active barrancas or the vent region, and in areas characterized by the presence of human activity where natural fields or anthropologica 1 structures are present. 
Because the approach of automated methods, like the NDVI, was not successful in delineating the deposits in the barrancas and in the proximal areas, the lahar deposits were visually mapped.

Even though the visual mapping has the disadvantage of the speed of reproduction, the manual interpretation technique allows to achieve high accuracy for hazard detection and monitoring.

\subsection{Lahars modeling withLAHARZ}

Lahars are widespread phenomena in volcanic areas that can severely affect people and infrastructure (Pierson et al., 1990; Pierson et al., 1992; Janda et al., 1996; Scott et al., 2005; Scott et al., 1996; Lavigne et al., 2000a).

When they are generated by direct eruptive activity and the volcanic material moves downhill incorporating enough water to descend the slopes of the volcano, they are commonly called primary lahars. The primary lahars usually have bulky flows, are characterized by high speeds $(>20 \mathrm{~m} / \mathrm{s})$ and can travel longdistances. Meanwhile, the secondary lahars occur from the remobilization of ash (tephra) layers by heavy rainfall and are typical of regions with high precipitation like Guatemala. On the other side, the secondary lahars have lower speed, volume and they can travel shorter distances, but they are the most frequent during periods of rain (Cando-Jácome and Martínez-Graña, 2019).

Therefore, the lahars can potentially jeopardize people and properties located next to the barrancas when the volcanic materials accumulated on the upper slopes can turn dangerous lahars when the rainy season comes. To predict lahar zones and minimize the loss of human life and property it is important to create hazard maps, review historical records, and to analyze lahar spreading areas. Predicting the initiation area is crucial to the assessment of rainfall triggered lahar volumes and potential runout (Iverson, 1997). 
Most of the available lahar-hazard assessments are based on the analysis of lahar spreading areas and an example of a model routinely used include the empirical model LAHARZ (Iverson et al., 1998; Schilling, 1998; Manville et al., 2013; Baumann et al., 2018)

LaharZ is a rapid, objective, and reproducible method of delineating lahar hazards created by the United States Geological Survey. It is a semiempirical model based on statistical analyses of lahar-inundation data from nine volcanoes in the United States of America, Mexico, Colombia, Canada and Philippines.

Laharz is executed within a Geographical Information System(GIS) and, using predictive equations, delineates lahars-inundation hazard zones on a Digital Elevation Model (DEM) for a variety of lahar volumes and represents gradations of the inundation hazard.

The software main analysis tools, which is used for delineating "distal hazard" areas, can be used to predict the inundation zones along channels and alluvial/fluvia 1 terrains adjacent and near to such channels. This method uses two semi-empirical equations derived by Iverson et al. (1998) that predict the valley cross-sectional area (A) and planimetric area (B) inundated by lahars with various volumes (V):

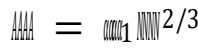

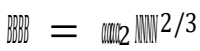

Where $\alpha \alpha \alpha \alpha_{1}=0.05$ and $\alpha \alpha \alpha \alpha_{2}=200$ as constant values, and V is the volume of the lahar.

To determine the proportional coefficient, the two equations were converted into logarithms and, using a regression analysis, a "2/3 slope" predictive model was proposed. 
Prior to generating potential lahar-inundation areas, LAHARZ must execute a series of steps, to remove any errors from the DEM, create superficial hydrologic grids, depict an energy cone with a user-defined slope and produce a proximal-hazard zone boundary selecting a drainage system and a volume input.

LAHARZ must create and use surface hydrology grids in order to limit processing to only cells that form streams within drainages. It uses GRID surface hydrology functions to derive the direction of flow out of every cell in the DEM creating a flow direction grid. The flow accumulation function creates a flow accumulation grid and, using values in the flow direction grid, assigns each cell in the flow accumulation grid a value that is the sum of the number of cells that flow into it (Schilling, 1998).

For this work a default stream-delineation threshold value of 1000 cells has been used, for this reason, where the flow accumulation grid was greater than this stream threshold value, a grid identifying cell locations was created. During this first step called "Create Surface Hydrology Grids", four different grids with four specific suffixes were developed: a)"fill" for the filledDEM, b) "dir" for the flow direction grid, c) "flac" for the flow accumulation grid and d) "strd" for the stream delineation grid.

The LAHARZ software also includes a module to delineate proximal hazard areas based on the energy-line cone concept (e.g. Salinas et al., 2009), but this is not relevant for our purposes and was therefore not pursued in our modeling.

After the "Create Surface Hydrology Grids" a "Lahars Distal Zones" step was initiated. Through this menu the filled DEM was selected, along with a volume and a starting coordinates text file.

The lahar zones simulated using the LAHARZ program were chosen based on the best representative lahar polygons, detected previously using the PlanetScope satellite images. 
Eventually, the detected lahar zones were compared with the simulated potential zones and verified.

The lahar volumes have been obtained from the Iverson equation

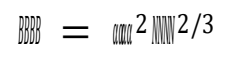

Where $\mathrm{B}$, the planimetric area, corresponds to each polygon area calculated as a geometry in the ArcMap shapefile's attribute table. Manipulating the equation, the volume $\mathrm{V}$ was solved for each different polygon; it is possible to see the different volume of each polygon in the following tables.

Table 1 - Area and volume of each polygon visually mapped in the January 2017 - July

\begin{tabular}{|c|c|c|}
\hline \multicolumn{3}{|c|}{ 2017 period } \\
\hline January 2017 - July 2017 & Are a m $^{2}$ & Volume $^{\mathbf{3}}$ \\
\hline Pantaleon 1 & 243672.678 & 30071.1707 \\
\hline Ceniza 1 & 351442.604 & 52124.3894 \\
\hline Ceniza 2 & 216108.0395 & 25149.6681 \\
\hline
\end{tabular}

Table 2 - Area and volume of each polygon visually mapped in the July 2017 - October 2017 period

\begin{tabular}{|c|c|c|}
\hline July 2017-October 2017 & Are a m & Volume $\mathbf{~ m}^{\mathbf{3}}$ \\
\hline Pantaleon 2 & 282141.7 & 39867.53 \\
\hline Pantaleon 3 & 475734.16 & 116011.6 \\
\hline Taniluya 1 & 76538.27542 & 7486.4 \\
\hline Ceniza 3 & 357363 & 51994.1 \\
\hline Achiguate 1 & 265904.8744 & 48477.97 \\
\hline
\end{tabular}




\subsection{Rainfall statistical analysis of triggered lahars}

The tropical position of Guatemala causes rainfall at the Fuego volcano site to follow a seasonal pattern: a dry season that extends from November through April/May, and a rainy season that extends from May/June to October. This coincides as well with the tropical storms and hurricane season in the western Atlantic Ocean and Caribbean Sea. Therefore, due to its location in the Intertropical Convergence Zone, Guatemala is also commonly affected by cyclones, like Tropical Cyclone Agatha (May - June 2010) or Hurricane Stan (October 2005).

The extreme and the regular rainfall events that lead to extended and intense precipitations, can trigger landslides and debris flows on steeps slopes on Fuego volcano and other high slope terrains in the region, causing extensive sedimentation and deposition of laharic material downstream.

The laharic activity during normal rain conditions is almost exclusively restricted to drainages that have received pyroclastic flow deposits, which usually includes seven Barrancas: Seca, Taniluya, Ceniza, Trinidad, El Jute, Las Lajas, and Honda.

To better understand how rainfall affects the trigger of lahars, rainfall data from three stations in the Fuego volcano area has been analyzed. The three stations are El Platanar (14.56 ${ }^{\circ}$ latitude North, $90.94^{\circ}$ longitude West), and Costa Brava (14.21 ${ }^{\circ}$ latitude North, $90.92^{\circ}$ longitude West), belonging to the Guatemalan "Instituto Privado de Investigacion sobre el Cambio Climatico" (https://icc.org.gt/es/conozca-la-red-de-estaciones-

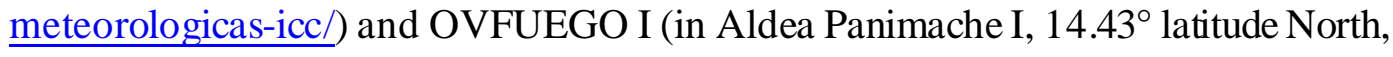
$90.93^{\circ}$ longitude West), which belongs to the Guatemalan "Instituto Nacional de Sismologia, Vulcanologia , Meteorologia e Hidrologia" (INSIVUMEH). El Platanar is located to the northwest of the volcano, Costa Brava to the south of the volcano and OVFUEGO I to the south west. 
The datasets contained rainfall values recorded every 15 minutes, from January 2016 to November 2018 for the El Platanar and the Costa Brava stations, and from May 2018 to November 2018 for the OVFUEGO I station.

The analysis has been carried out based on the eruptions and lahar events which have taken place between 2016 and 2018, with the results summarized in the Table 3.

The triggering of landslides and debris flows, including lahars, has been found to relate to both the intensity and the duration of the preceding rainfall (e. g. Guzzetti et al., 2008). To assess how rainfall intensity and duration affected the lahar generation four our case study we estimated the rainfall accumulations leading up to particular lahar events, for different time windows, to define critical intensities and durations for triggering lahar events. Summing up the 15 minutes rainfall data, different durations were taken into account and, for each interval, the maximum value was calculated. The duration period considered are:30 minutes, 1 hour, 3 hours, 6 hours, 12 hours, 24 hours, 48 hours, 72 hours, 96 hours, 120 hours, 144 hours, 168 hours and 196 hours before the lahar event.

Eventually, rainfall intensity has been defined as the ratio of the total amount of rain (rainfall depth) falling during each given period to the duration of the period; it has been expressed in-depth units per unit time as millimeters per hour ( $\mathrm{mm} / \mathrm{h})$.

The time between each lahar event and the last eruptive paroxysms recorded by INSIVUMEH was also analyzed, to find possible relations between the eruptions and posterior lahars generation. The distribution of times between eruptions and lahar occurrence was assessed visually, to observe any obvious changes in the frequency of lahar occurrence after eruptions. Critical triggering intensities obtained from the previous analysis were also compared with times since the last eruption. 


\begin{tabular}{|c|c|c|}
\hline \multirow{2}{*}{$\begin{array}{l}\text { Lahars } \\
\text { DATE }\end{array}$} & \multicolumn{2}{|c|}{ Paroxysms } \\
\hline & start & end \\
\hline $29 / 04 / 2016$ & 11-Apr-2016 & 14-Apr-2016 \\
\hline $19 / 05 / 2016$ & 18-May-2016 & 19-May-2016 \\
\hline $05 / 06 / 2016$ & 21-Мay-2016 & 23-May-2016 \\
\hline $18 / 06 / 2016$ & 21-May-2016 & 23-May-2016 \\
\hline $04 / 07 / 2016$ & 24-Jun-2016 & 26-Jun-2016 \\
\hline $15 / 07 / 2016$ & 24-Jun-2016 & 26-Jun-2016 \\
\hline $19 / 07 / 2016$ & 24-Jun-2016 & 26-Jun-2016 \\
\hline $22 / 07 / 2016$ & 24-Jun-2016 & 26-Jun-2016 \\
\hline $23 / 07 / 2016$ & 24-Jun-2016 & 26-Jun-2016 \\
\hline $28 / 07 / 2016$ & 28-Jul-2016 & 29-Jul-2016 \\
\hline $29 / 07 / 2016$ & 28-Jul-2016 & 29-Jul-2016 \\
\hline $07 / 08 / 2016$ & 28-Jul-2016 & 29-Jul-2016 \\
\hline $08 / 08 / 2016$ & 28-Jul-2016 & 29-Jul-2016 \\
\hline $15 / 08 / 2016$ & 28-Jul-2016 & 29-Jul-2016 \\
\hline $16 / 08 / 2016$ & 28-Jul-2016 & 29-Jul-2016 \\
\hline $28 / 08 / 2016$ & 28-Jul-2016 & 29-Jul-2016 \\
\hline $02 / 09 / 2016$ & 28-Jul-2016 & 29-Jul-2016 \\
\hline $18 / 09 / 2016$ & 6-Sep-2016 & 8-Sep-2016 \\
\hline $21 / 09 / 2016$ & 6-Sep-2016 & 8-Sep-2016 \\
\hline $22 / 09 / 2016$ & 6-Sep-2016 & 8-Sep-2016 \\
\hline $26 / 09 / 2016$ & 6-Sep-2016 & 8-Sep-2016 \\
\hline $14 / 05 / 2017$ & 4-May-2017 & 5-Мay-2017 \\
\hline $19 / 05 / 2017$ & 4-Мay-2017 & 5-Мay-2017 \\
\hline $27 / 05 / 2017$ & 4-May-2017 & 5-May-2017 \\
\hline $29 / 05 / 2017$ & 4-May-2017 & 5-Мay-2017 \\
\hline $01 / 06 / 2017$ & 4-Мay-2017 & 5-May-2017 \\
\hline $02 / 06 / 2017$ & 4-Мay-2017 & 5-May-2017 \\
\hline $04 / 06 / 2017$ & 4-May-2017 & 5-Мay-2017 \\
\hline $05 / 06 / 2017$ & 5-Jun-2017 & 6-Jun-2017 \\
\hline $07 / 06 / 2017$ & 5-Jun-2017 & 6-Jun-2017 \\
\hline $09 / 06 / 2017$ & 5-Jun-2017 & 6-Jun-2017 \\
\hline $10 / 06 / 2017$ & 5-Jun-2017 & 6-Jun-2017 \\
\hline $12 / 06 / 2017$ & 5-Jun-2017 & 6-Jun-2017 \\
\hline $13 / 06 / 2017$ & 13-Jun-2017 & 13-Jun-2017 \\
\hline $18 / 06 / 2017$ & 13-Jun-2017 & 13-Jun-2017 \\
\hline $05 / 07 / 2017$ & 13-Jun-2017 & 13-Jun-2017 \\
\hline $16 / 07 / 2017$ & 11-Jul-2017 & 12-Jul-2017 \\
\hline $08 / 08 / 2017$ & 7-Aug-2017 & 8-Aug-2017 \\
\hline 09/08/2017 & 7-Aug-2017 & 8-Aug-2017 \\
\hline $25 / 08 / 2017$ & 19-Aug-2017 & 21-Aug-2017 \\
\hline $03 / 09 / 2017$ & 19-Aug-2017 & 21-Aug-2017 \\
\hline $04 / 09 / 2017$ & 19-Aug-2017 & 21-Aug-2017 \\
\hline $05 / 09 / 2017$ & 19-Aug-2017 & 21-Aug-2017 \\
\hline $06 / 09 / 2017$ & 19-Aug-2017 & 21-Aug-2017 \\
\hline
\end{tabular}

\begin{tabular}{|c|c|c|}
\hline 08/09/2017 & 19-Aug-2017 & 21-Aug-2017 \\
\hline $27 / 09 / 2017$ & $12-\operatorname{Sep}-2017$ & 13-Sep-2017 \\
\hline $29 / 09 / 2017$ & 27-Sep-2017 & 28-Sep-2017 \\
\hline 01/10/2017 & 27-Sep-2017 & 28-Sep-2017 \\
\hline $02 / 10 / 2017$ & 27-Sep-2017 & 28-Sep-2017 \\
\hline 04/10/2017 & 27-Sep-2017 & 28-Sep-2017 \\
\hline $22 / 11 / 2017$ & 5-Nov-2017 & 7-Nov-2017 \\
\hline 09/04/2018 & 31-Jan-2018 & 1-Feb-2018 \\
\hline $10 / 05 / 2018$ & 31-Jan-2018 & 1-Feb-2018 \\
\hline $16 / 05 / 2018$ & 31-Jan-2018 & 1-Feb-2018 \\
\hline $17 / 05 / 2018$ & 31-Jan-2018 & 1-Feb-2018 \\
\hline $18 / 05 / 2018$ & 31-Jan-2018 & 1-Feb-2018 \\
\hline $25 / 05 / 2018$ & 31-Jan-2018 & 1-Feb-2018 \\
\hline $03 / 06 / 2018$ & 3-Jun-2018 & 3-Jun-2018 \\
\hline $06 / 06 / 2018$ & 3-Jun-2018 & 3-Jun-2018 \\
\hline $08 / 06 / 2018$ & 3-Jun-2018 & 3-Jun-2018 \\
\hline 09/06/2018 & 3-Jun-2018 & 3-Jun-2018 \\
\hline $10 / 06 / 2018$ & 3-Jun-2018 & 3-Jun-2018 \\
\hline $11 / 06 / 2018$ & 3-Jun-2018 & 3-Jun-2018 \\
\hline $12 / 06 / 2018$ & 3-Jun-2018 & 3-Jun-2018 \\
\hline $13 / 06 / 2018$ & 3-Jun-2018 & 3-Jun-2018 \\
\hline $14 / 06 / 2018$ & 3-Jun-2018 & 3-Jun-2018 \\
\hline $15 / 06 / 2018$ & 3-Jun-2018 & 3-Jun-2018 \\
\hline $16 / 06 / 2018$ & 3-Jun-2018 & 3-Jun-2018 \\
\hline $17 / 06 / 2018$ & 3-Jun-2018 & 3-Jun-2018 \\
\hline $18 / 06 / 2018$ & 3-Jun-2018 & 3-Jun-2018 \\
\hline $19 / 06 / 2018$ & 3-Jun-2018 & 3-Jun-2018 \\
\hline $20 / 06 / 2018$ & 3-Jun-2018 & 3-Jun-2018 \\
\hline $21 / 06 / 2018$ & 3-Jun-2018 & 3-Jun-2018 \\
\hline $22 / 06 / 2018$ & 3-Jun-2018 & 3-Jun-2018 \\
\hline $23 / 06 / 2018$ & 3-Jun-2018 & 3-Jun-2018 \\
\hline $26 / 06 / 2018$ & 3-Jun-2018 & 3-Jun-2018 \\
\hline $30 / 06 / 2018$ & 3-Jun-2018 & 3-Jun-2018 \\
\hline 01/07/2018 & 3-Jun-2018 & 3-Jun-2018 \\
\hline $29 / 07 / 2018$ & 3-Jun-2018 & 3-Jun-2018 \\
\hline $30 / 07 / 2018$ & 3-Jun-2018 & 3-Jun-2018 \\
\hline 01/08/2018 & 3-Jun-2018 & 3-Jun-2018 \\
\hline $02 / 08 / 2018$ & 3-Jun-2018 & 3-Jun-2018 \\
\hline 05/08/2018 & 3-Jun-2018 & 3-Jun-2018 \\
\hline 09/08/2018 & 3-Jun-2018 & 3-Jun-2018 \\
\hline $13 / 08 / 2018$ & 3-Jun-2018 & 3-Jun-2018 \\
\hline $14 / 08 / 2018$ & 3-Jun-2018 & 3-Jun-2018 \\
\hline $17 / 08 / 2018$ & 3-Jun-2018 & 3-Jun-2018 \\
\hline $26 / 08 / 2018$ & 3-Jun-2018 & 3-Jun-2018 \\
\hline $27 / 08 / 2018$ & 3-Jun-2018 & 3-Jun-2018 \\
\hline $28 / 08 / 2018$ & 3-Jun-2018 & 3-Jun-2018 \\
\hline $29 / 08 / 2018$ & 3-Jun-2018 & 3-Jun-2018 \\
\hline
\end{tabular}

\begin{tabular}{|l|l|l|}
\hline $30 / 08 / 2018$ & 3-Jun-2018 & 3-Jun-2018 \\
\hline $31 / 08 / 2018$ & 3-Jun-2018 & 3-Jun-2018 \\
\hline $01 / 09 / 2018$ & 3-Jun-2018 & 3-Jun-2018 \\
\hline $02 / 09 / 2018$ & 3-Jun-2018 & 3-Jun-2018 \\
\hline $03 / 09 / 2018$ & 3-Jun-2018 & 3-Jun-2018 \\
\hline $04 / 09 / 2018$ & 3-Jun-2018 & 3-Jun-2018 \\
\hline $05 / 09 / 2018$ & 3-Jun-2018 & 3-Jun-2018 \\
\hline $09 / 09 / 2018$ & 3-Jun-2018 & 3-Jun-2018 \\
\hline $10 / 09 / 2018$ & 3-Jun-2018 & 3-Jun-2018 \\
\hline $11 / 09 / 2018$ & 3-Jun-2018 & 3-Jun-2018 \\
\hline $12 / 09 / 2018$ & 3-Jun-2018 & 3-Jun-2018 \\
\hline $13 / 09 / 2018$ & 3-Jun-2018 & 3-Jun-2018 \\
\hline $14 / 09 / 2018$ & 3-Jun-2018 & 3-Jun-2018 \\
\hline $15 / 09 / 2018$ & 3-Jun-2018 & 3-Jun-2018 \\
\hline $16 / 09 / 2018$ & 3-Jun-2018 & 3-Jun-2018 \\
\hline $19 / 09 / 2018$ & 3-Jun-2018 & 3-Jun-2018 \\
\hline $20 / 09 / 2018$ & 3-Jun-2018 & 3-Jun-2018 \\
\hline $21 / 09 / 2018$ & 3-Jun-2018 & 3-Jun-2018 \\
\hline $23 / 09 / 2018$ & 3-Jun-2018 & 3-Jun-2018 \\
\hline $24 / 09 / 2018$ & 3-Jun-2018 & 3-Jun-2018 \\
\hline $25 / 09 / 2018$ & 3-Jun-2018 & 3-Jun-2018 \\
\hline $26 / 09 / 2018$ & 3-Jun-2018 & 3-Jun-2018 \\
\hline $27 / 09 / 2018$ & 3-Jun-2018 & 3-Jun-2018 \\
\hline $06 / 10 / 2018$ & 3-Jun-2018 & 3-Jun-2018 \\
\hline $08 / 10 / 2018$ & 3-Jun-2018 & 3-Jun-2018 \\
\hline $09 / 10 / 2018$ & 3-Jun-2018 & 3-Jun-2018 \\
\hline $13 / 10 / 2018$ & 12-ott-2018 & 13-ott-2018 \\
\hline $16 / 10 / 2018$ & 12-ott-2018 & 13-ott-2018 \\
\hline $17 / 10 / 2018$ & 12-ott-2018 & 13-ott-2018 \\
\hline $18 / 10 / 2018$ & 12-ott-2018 & 13-ott-2018 \\
\hline $20 / 10 / 2018$ & 12-ott-2018 & 13-ott-2018 \\
\hline $03 / 11 / 2018$ & 12-ott-2018 & 13-ott-2018 \\
\hline $29 / 11 / 2018$ & 18-nov-2018 & 19-nov-2018 \\
\hline $30 / 11 / 2018$ & 18-nov-2018 & 19-nov-2018 \\
\hline
\end{tabular}

Table 3 - Lahars and paroxysms occurred between 2016 and 2018 


\section{Results}

\subsection{Satellite remote sensing}

Lahars deposits mapped with the methods previously described were detected into a GIS platform (ArcMap, Esri) for interpretations and analysis. In this chapter, it is possible to see the maps of the all area during four periods of time:

- January 2017 - July 2017

- July 2017 - October 2017

- December 2017 - January 2018

- January 2018 - July 2018

All the images used were PlanetScope images, similar to the products used by Aldeghi et al., 2019. The images had similar ground resolution, with a nominal resolution of $3 \mathrm{~m}$, but slightly larger ground resolutions depending on local slope and satellite viewing angle. Sensor spectral characteristics were the same for all images, and they were also acquired at similar times during the day (between 15:46 and 17:00 UTC), resulting in similar lighting conditions. Table 4 lists some of the characteristics of these images.

Table 4. Basic acquisition characteristics of the PlanetScope images used in the study .

\begin{tabular}{|c|c|c|c|c|c|c|c|}
\hline 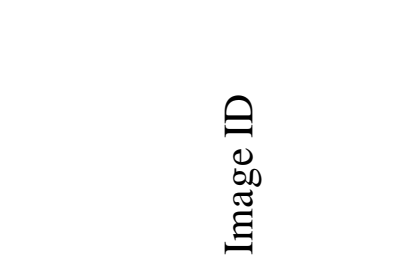 & $\stackrel{\mathscr{\Xi}}{\tilde{\theta}}$ & 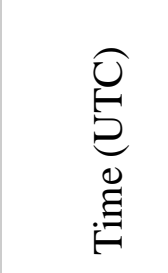 & 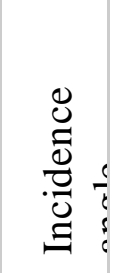 & 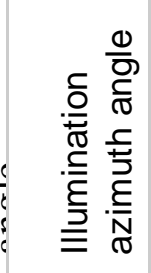 & 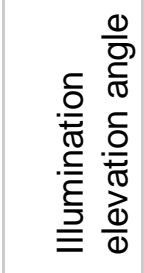 & 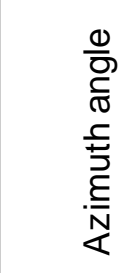 & 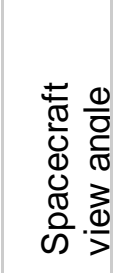 \\
\hline 20170703_154614_103e & 2017-07-03 & $15: 46: 14$ & 3.54 & 70.35 & 55.89 & 11.35 & 3.28 \\
\hline 20170703_154615_103e & 2017-07-03 & $15: 46: 15$ & 3.56 & 70.26 & 55.86 & 11.34 & 3.30 \\
\hline 20170703_154616_103e & 2017-07-03 & $15: 46: 16$ & 3.55 & 70.17 & 55.82 & 11.33 & 3.30 \\
\hline 20170703_154634_1039 & 2017-07-03 & $15: 46: 34$ & 5.42 & 70.42 & 55.91 & 11.31 & 5.02 \\
\hline 20170703_154635_1039 & 2017-07-03 & $15: 46: 35$ & 5.41 & 70.33 & 55.88 & 11.29 & 5.02 \\
\hline 20170703_154636_1039 & 2017-07-03 & $15: 46: 36$ & 5.43 & 70.24 & 55.85 & 11.32 & 5.03 \\
\hline 20170703_154638_1039 & 2017-07-03 & $15: 46: 38$ & 5.41 & 70.15 & 55.82 & 11.30 & 5.01 \\
\hline
\end{tabular}




\begin{tabular}{|c|c|c|c|c|c|c|c|}
\hline 20170703_155208_0e26 & 2017-07-03 & 15:52:08 & 0.36 & 70.01 & 56.90 & 11.76 & 0.30 \\
\hline 20170703_155209_0e26 & 2017-07-03 & $15: 52: 09$ & 0.33 & 69.91 & 56.87 & 11.73 & 0.28 \\
\hline 20170703_155210_0e26 & 2017-07-03 & $15: 52: 10$ & 0.35 & 69.82 & 6.84 & 11.74 & 0.29 \\
\hline 20170703_155211_0e26 & 2017-07-03 & $15: 52: 11$ & 0.34 & 69.73 & 56.80 & 11.73 & 0.28 \\
\hline 20170125_154817_0e26 & $2017-01-25$ & $15: 48: 17$ & 0.19 & 131.22 & 40.84 & 11.60 & 0.15 \\
\hline 20171031_155219_103d & 2017-10-31 & $15: 52: 19$ & 3.02 & 134.29 & 49.77 & 11.26 & 2.79 \\
\hline 20171031_155220_103d & 2017-10-31 & $15: 52: 20$ & 3.03 & 134.22 & 49.81 & 11.24 & 2.81 \\
\hline 20171031_155221_103d & 2017-10-31 & $15: 52: 21$ & 3.03 & 134.15 & 49.85 & 11.17 & 2.80 \\
\hline 20171031_155222_103d & 2017-10-31 & $15: 52: 22$ & 3.03 & 134.09 & 49.89 & 11.22 & 2.81 \\
\hline 20170125_154816_0e26 & $2017-01-25$ & $15: 48: 16$ & 0.20 & 131.27 & 40.80 & 11.64 & 0.16 \\
\hline 20171225_155453_1025 & $2017-12-25$ & $15: 54: 53$ & 0.75 & & 40.81 & & \\
\hline 20171225_155454_1025 & $2017-12-25$ & $15: 54: 54$ & 0.78 & 139.74 & & & \\
\hline 20171225_155455_1025 & $2017-12-25$ & & 0.76 & & & & 0.75 \\
\hline 20171225_155456_1025 & $2017-12-25$ & $15: 54: 56$ & 0.77 & 139.65 & 40.95 & 11.26 & 0.76 \\
\hline 20171225_155453_1025 & $2017-12-25$ & $15: 54: 53$ & 0.75 & 139.79 & 40.81 & 11.28 & 0.73 \\
\hline 20171225_155454_1025 & $2017-12-25$ & $15: 54: 54$ & 0.78 & 139.74 & 40.86 & 11.33 & 0.76 \\
\hline 20171225_155455_1025 & 2017-12-25 & $15: 54: 55$ & 0.76 & 139.70 & 40.90 & 11.29 & 0.75 \\
\hline 20171225_155456_1025 & $2017-12-25$ & $15: 54: 56$ & 0.77 & 139.65 & 40.95 & 11.26 & 0.76 \\
\hline 20170703_154634_1039 & 2017-07-03 & $15: 46: 34$ & 5.42 & 70.42 & 55.91 & 11.31 & 5.02 \\
\hline 20170703_154635_1039 & 2017-07-03 & $15: 46: 35$ & 5.41 & 70.33 & 55.88 & 11.29 & 5.02 \\
\hline 20171225_170014_0f32 & $2017-12-25$ & 17:00:14 & 2.17 & 157.09 & 49.19 & 349.23 & 2.02 \\
\hline 20171225_170015_0f32 & $2017-12-25$ & 17:00:15 & 2.15 & 157.11 & 49.13 & 349.26 & 2.00 \\
\hline 20171225_170016_0f32 & $2017-12-25$ & 17:00:16 & 2.15 & 157.13 & 49.08 & 349.21 & 2.00 \\
\hline 20171225_170013_0f32 & $2017-12-25$ & $17: 00: 13$ & 2.16 & 157.08 & 49.25 & 349.17 & 2.02 \\
\hline
\end{tabular}

During the 2018 events the Barrancas Las Lajas, Pantaleon, Ceniza and Achiguate have been affected by the lahars. Thisled to change in sedimentation coverage, channel avulsion and shifting and morphological changes not only along the Barrancas but also over cultivated areas (mainly sugar cane), or over the small village of Palo Verde and some larger villages like El Porvenir, near the Barranca Pantaleon. Even though the 
major changes occurred after the $3^{\text {rd }}$ June 2018 eruption, it is possible to see that the changes were already slowly happening even during 2017.

Figure 4.1 shows the mapped changes, interpreted as lahar inundation areas along the barranca systems that drain Fuego volcano, for different periods of time, throughout 2017. Although some of these areas may correspond to pyroclastic density current inundation areas, rather than lahar inundation areas, in particular those areas closest to the summit vent (e. g. the Jan - July 2017 changes on the West flank mapped in green). 


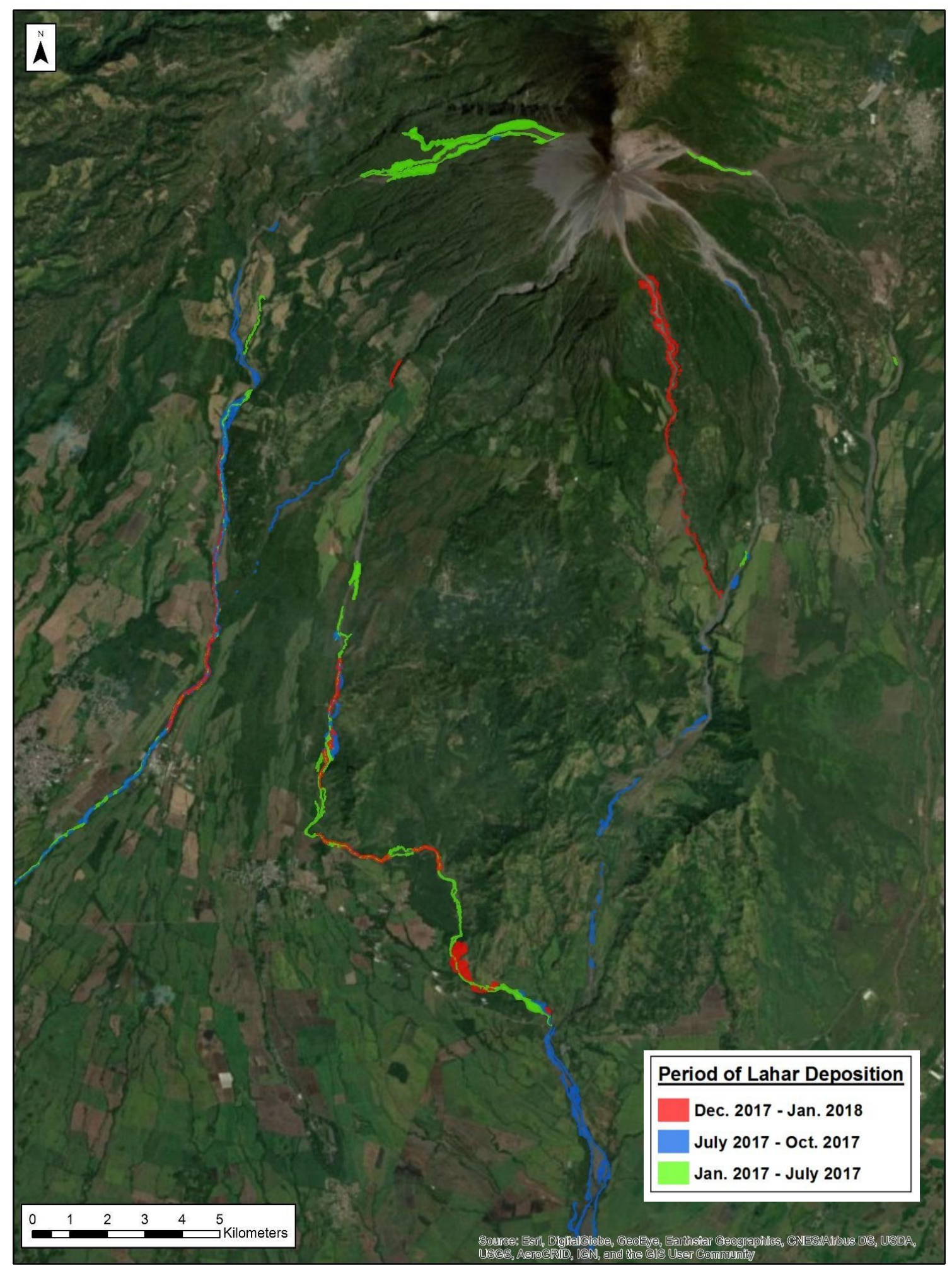

Figure 4.1. Map showing the associated with deposition of material for different time periods between January 2017 and January 2018. 
The December 2017 - January 2018 period shows the minor changes probably because it's only a one-month interval period and occur in the dry season where it's not possible to detect a lot of changes. In this section, only the whole area and an example of the detailed barranca are shown, all the other close sections of the visually mapped lahars are shown in Appendix A.

Mapping of changes along the channels with lahar activity shows areas that were inactive before 2017 but were inundated by lahars during the 2017 rainy season. Figure 4.1 shows such areas along the Ceniza and Pantaleon rivers, the lahar inundation areas adjacent to the channels, affecting agricultural land, and movingclose to populated areas, and affecting some small infrastructure. This is consistent with reports of lahar inundation and damage starting in June 2017, by INSIVUMEH (INSIVUMEH, 2017).

The most obvious changes seen in the satellite imagery were changes in surface reflectivity indicating a change from vegetated surface before the terrain was covered by lahar material, to unvegetated surface after the lahar inundation, particularly in the spectral bands that are sensitive to vegetation (e. g. the visible green and near-infrared bands). Such spectral reflectivity changes what allowed us to map most of the inundation zones for areas that were previously inactive and were covered with vegetation. Areas that had been recently active prior to the 2017 lahar season (e. g. the permanently active lahar channels) are not easy to map because of the lack of contrast between the before and after scenes, but such areas are least important targets to map from many perspectives (e. g. hazard assessment) because they are expected to be affected by lahar activity every year.

Other areas seemed to also show changes in the satellite imagery but were confirmed to only correspond to vegetation changes (e. g. seasonal crop variation or burned vegetation due to forest and bush fires) not related to lahar activity, e. g. along the Barranca Trinidad channel and adjacent interfluvial terrain. 
The mapped lahar inundation areas allow us to assess how far from the active channel the lahar material moved during those events, and potentially compare such lahar inundation extensions with modeling results obtained through the LaharZ software.

Figure 4.2 also includes the mapped changes for the January to July 2018 period, together with the mapped areas shown infigure 4.1. The changes in the January - July 2018 period are dominated by the deposits from (and following) the June $3^{\text {rd }} 2018$ eruption, and a large part of those deposits correspond to pyroclastic density current deposits, particularly those closer to the summitvent. The analysis of the 2018 deposits goes beyond the aim of this study and are show here just to provide a context for the changes observed in the 2017 period. 


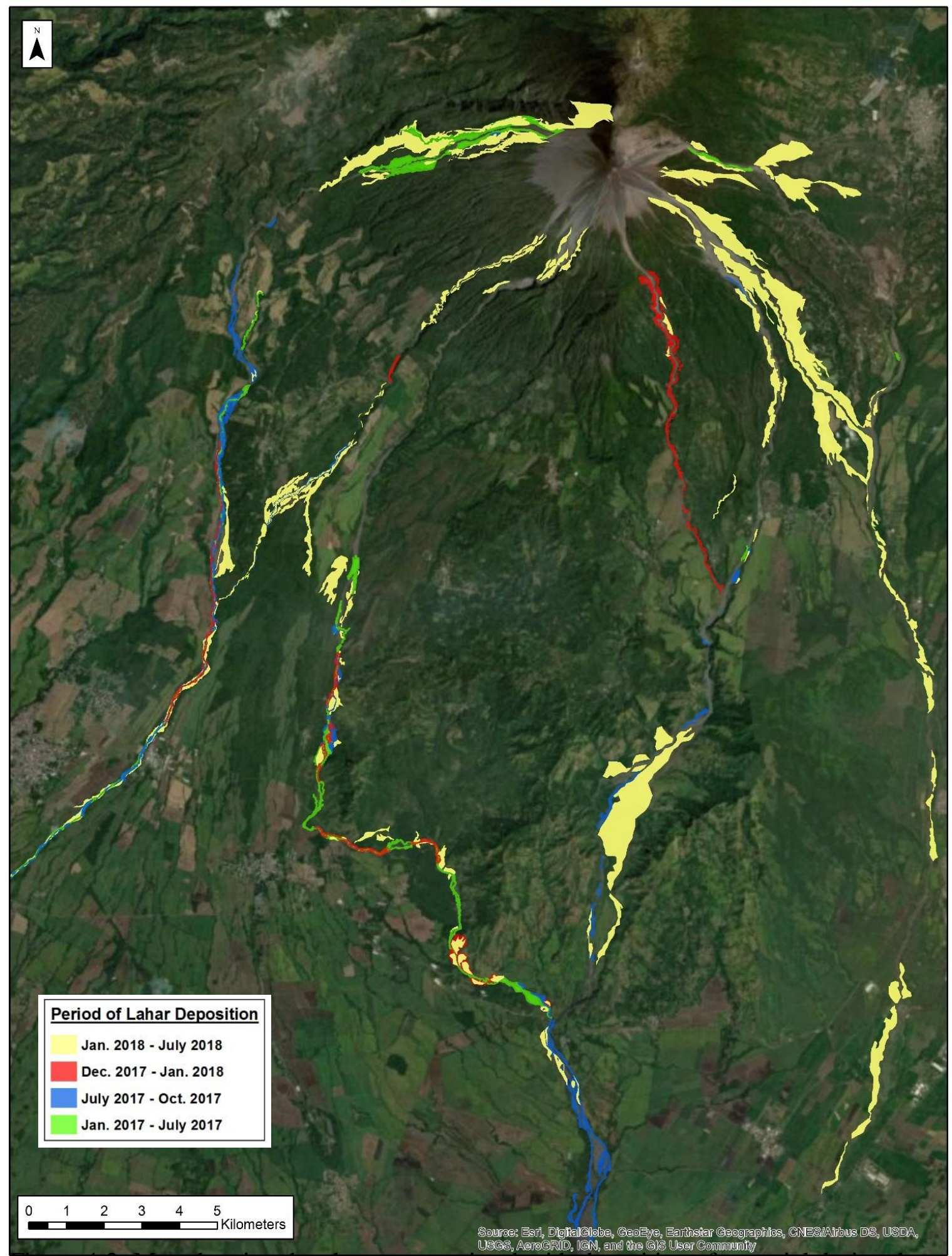

Figure 4.2. Map showing the changes associated with deposition of material during the January to July 2018 time period, overlaid on the changes corresponding to the January 2017 to January 2018 period, as shown in figure 4.1. 


\subsection{Laharz}

The results of lahar trajectories using LAHARZ has been compared to the visual mapping of deposits using the PlanetScope images.

The matching (or mismatching) between the remote sensing based mapping of deposits and the modeled inundation areas could providea first order idea of how good the model predicts the actual laharbehavior. It ishowever important to keep in mind that models like LAHARZ are not exactly meant to reproduce the cumulative behavior of lahars like those mapped using the remote sensing tools described in this study, LAHARZ as a model isjust intended to provide a broad idea of what areas may be exposed to lahar hazards, from single lahar events that fit some particular characteristics (e. g. similar to those used to calibrate the model). The lahar inundation areas obtained from the remote sensing methods instead represent the cumulative effect of potentially many lahars events, and those lahar events may be quitedifferent from the lahar types that were used to calibrate the model. Nevertheless, the comparison is instructive and sheds some light on both the capabilities and limitations of using such models to predict possible hazard exposure and inundation areas of lahars.

We used the ALOS Global Digital Surface Model "ALOS World 3D - 30m (AW3D30)" digital elevation model (DEM), with a $30 \mathrm{~m}$ resolution (pixel size). This DEM was generated from ALOS-PRISM optical imagery acquired between 2006 and 2011, and therefore characterizes the state of the topography from those years, which means that there could be some outdated data problems in comparing the results with the 2017 lahar behavior, but based on our field knowledge of the area we expect such variations to be minor.

Figure 4.3 shows a comparison between the mapped versus modeled lahar inundation area for the 2017 period along a stretch of the Pantaleon channel and adjacent areas. The LAHARZ simulation corresponds to a volume of $30071.71 \mathrm{~m}^{3}$. 

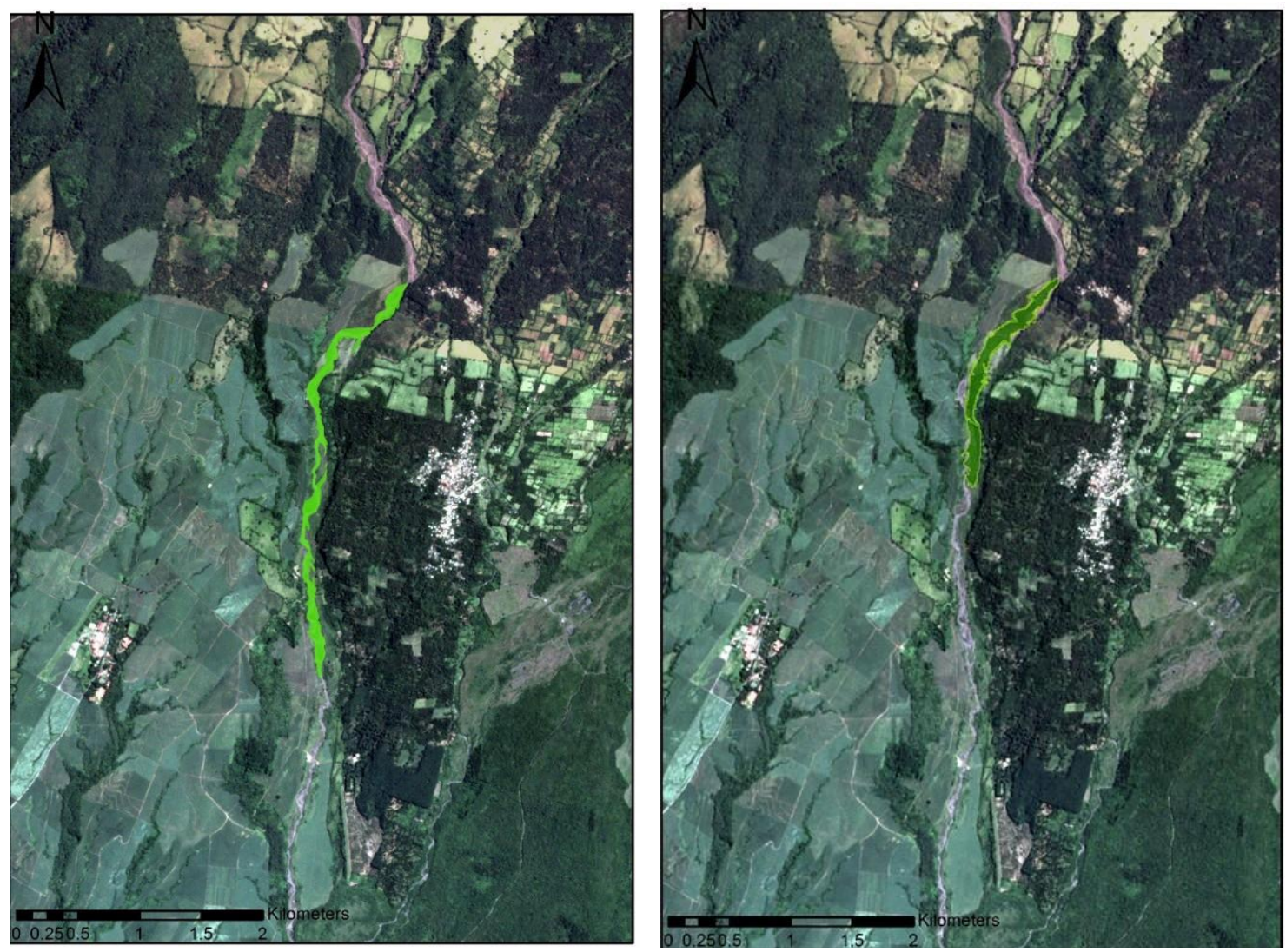

Figure 4.3. Comparison between satellite based mapping of lahar deposits from the 2017 lahar activity (left panel), and LAHARZ simulated inundation areas for the Pantaleon channel and adjacent areas (right panel).

The LAHARZ simulation result follows the channel outline but the inundation area doesn't reach as far as the actual mapped deposits show. On the other hand the lateral width of the inundated are produced by LAHARZ is much wider than the actual mapped inundation area. Changing the volume will result in either lengthening the reach of the modeled result by increasing the inputvolume, but at the same timeincreasing the width 
of the inundation area. Or decreasing the width of the inundation area by decreasing the volume, but at the same time shortening even more the reach of the inundation polygon.

This illustrates the main discrepancy observed from our modelling, that the LAHARZ outputs consistently tend to underestimate the distance that lahars will travel, while overestimate the width, as defined by the lateral distance from the channel, of the inundation areas. Perhaps a recalibration of the model, in how the planimetric and cross sectional areas are calculated, could produce better results for lahars like those observed at Fuego volcano.

It is possible to see that inconsistencies arise between the simulation results and the satellite images; this might be due to different problems that characterize the semiempirical model.

LAHARZ results show false irregular edges in the delineated inundation zones, called ragged edges. This can be caused by the lack of DEM accuracy, but a DEM with high spatial resolution does not necessarily guarantee a realistic lahar simulation either (Salinas et al., 2009). This is because the initial lahar volume remains constant, fillingin every cross-section with the same value of A independently of the channel's shape and without considering the bulkingand debulking that are frequent in lahars.

Although it might be difficult to collect a satisfactory amount of data to measure flow volume, cross-sectional area, and planimetric area for a certain volcano, specific coefficients should be applied for each volcano's characteristics rather than using an average coefficient for all cases. In the following images the visually mapped lahar, on the left, and the simulated event, on the right, are shown.

DEM artifacts and errors can also lead to erroneous results. Figure 4.4shows the comparison between inundation areas mapped from satellite images and the LAHARZ results (input volume of $25149.6681 \mathrm{~m}^{3}$ ) for another section of the Ceniza channel. The trajectory taken by the LAHARZ simulation is different from the actual trajectory 
followed by the lahar flows, as mapped from satellite images, which results in different inundation areas.
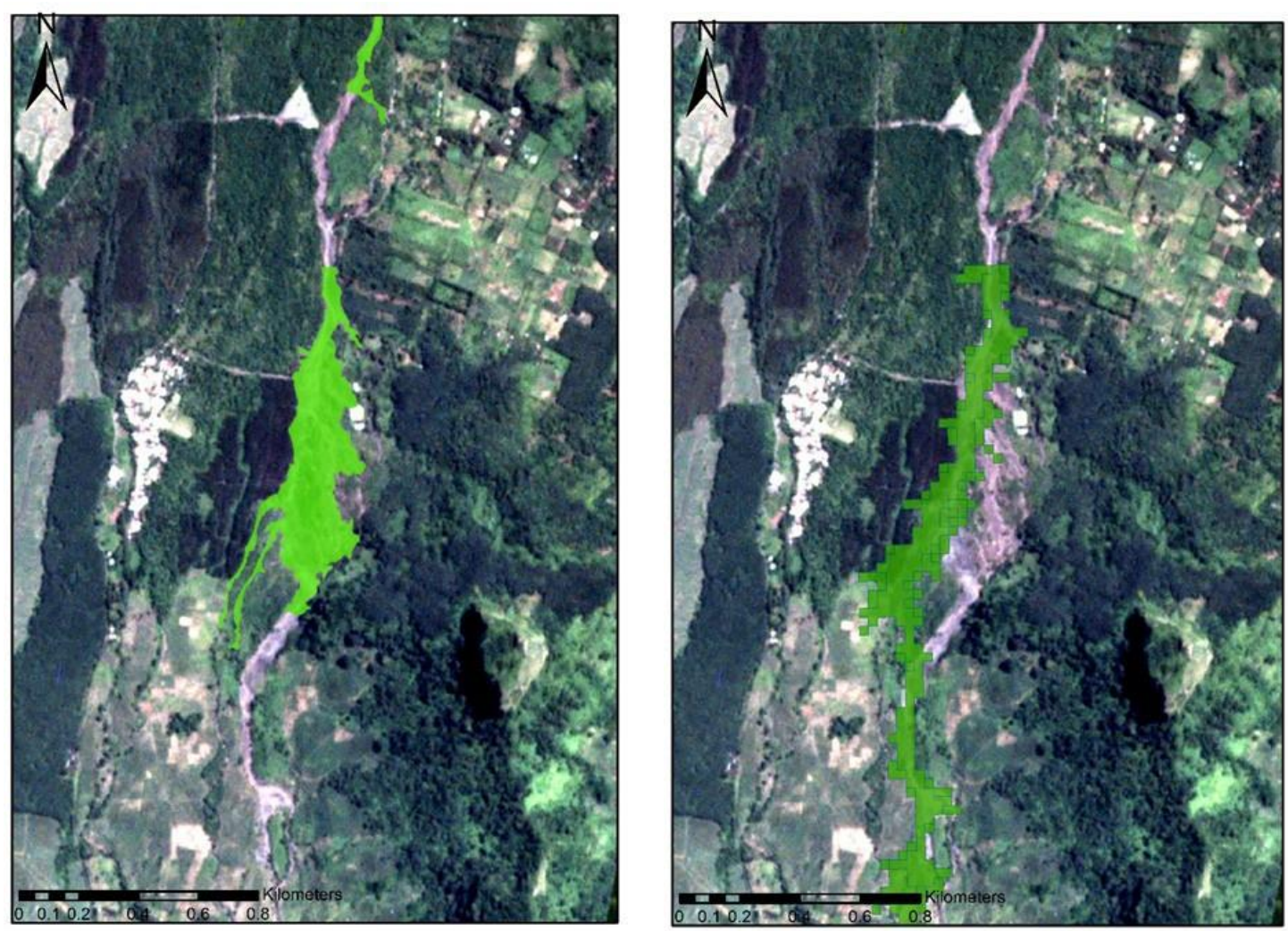

Figure 4.4. Lahar inundation areas based on satellite image mapping (left panel) compared with LAHARZ modeling with an input volume of $25149.67 \mathrm{~m} 3$ (right panel), for a stretch of the Ceniza channel.

It also important to consider that the LAHARZ model works under assumptions such as:

1) the inundation by past lahars can provide the information basis to predict inundation by future lahars;2) distal lahar hazards are confined to valleys that head on volcano flanks; 3) lahar volume largely controls the extent of inundation downstream;4) 
voluminous lahars occur less often than small lahars; and 5) no one can foretell the size of the next lahar to descend a given drainage (Iverson et al., 1998).

In this section only the two models of the January 2017 - July 2017 events have been shown, first of the Barranca Pantaleon and then of two events occurred in the Barranca Ceniza have been shown. For all the other models of January 2017 - July 2017 and July 2017 - October 2017 see Appendix B. 


\subsection{Rainfall}

Although we know that the main lahar triggering factor is the rainfall intensity, modeling how failure mechanisms vary with the rainfall intensity and frequency over long periods of time is difficult to do accurately. Indeed, other parameters must be considered such as the slope stability, the seismicity associated with eruptions and the thickness, grainsize and composition of the volcanic material; other considerations may also be important, for instance a more permeable material may have a quicker response to short and intense rains compared to a less permeable material, which may need extended events to let the water infiltrate and destabilize the slope. Such level of analysis goes far beyond the capacity of the LaharZ model.

To analyze the relationship between lahars and rainfall we will consider two hypotheses:

1. Lahars need a minimum value of rainfall to be triggered.

The occurrence of lahars, and in general debris flows and landslides triggered by rainfall, has been linked to minimum rainfall and intensity thresholds (e. g. Guzzetti et al. 2008 and references therein). We conducted an analysis of the minimumrainfall duration and intensity that would result in the occurrence of lahars. We used rainfall data from 3 rainfall measuring stations belonging to the "In stituto de Cambio Climatico" (https://redmet.icc.org.gt/) located in the vicinity of Fuego volcano, and the rainfall data from one station belonging to INSIVUMEH and located on the OVFUEGO volcano observatory. Rainfall data are given every 15 minutes, and record periods go from 2007 to 2019. We also use the catalog of lahars compiled by INSIVUMEH from 2016 through 2018 and which includes three rainy seasons and 126 days with recorded lahars.

Figure 4.5 shows the rainfall intensity and duration plots (blue circles) associated with the lahars contained in the INSIVUMEH lahar catalog, as recorded in three rainfall stations near the volcano. The figures also show the rainfall intensity and duration defined by Guzzetti et al. (2008), shown as a magenta line. It can be seen that for all stations the 
occurrence of lahars happens at intensity and durations much smaller than those defined by Guzzetti et al. (2008), which means that lahars will happen very easily at Fuego. The lower limitof the rainfall intensities associated with the occurrence of lahars follow a linear trend in the log-log space, with a slope of -1 . This indicates that if the rainfall intensity decreases by order of magnitude, but the duration of rainfall instead increases by an order of magnitude, the lahars will still be triggered.

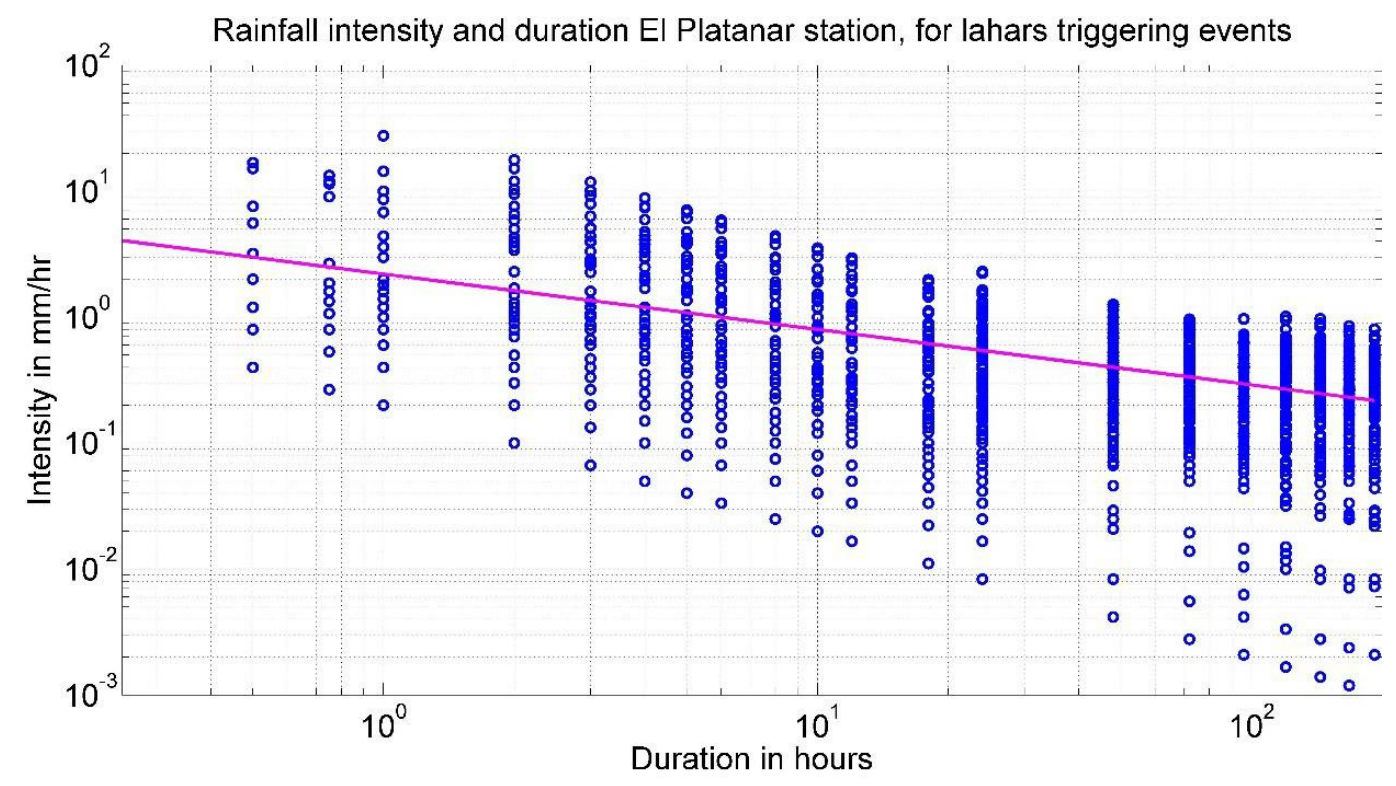



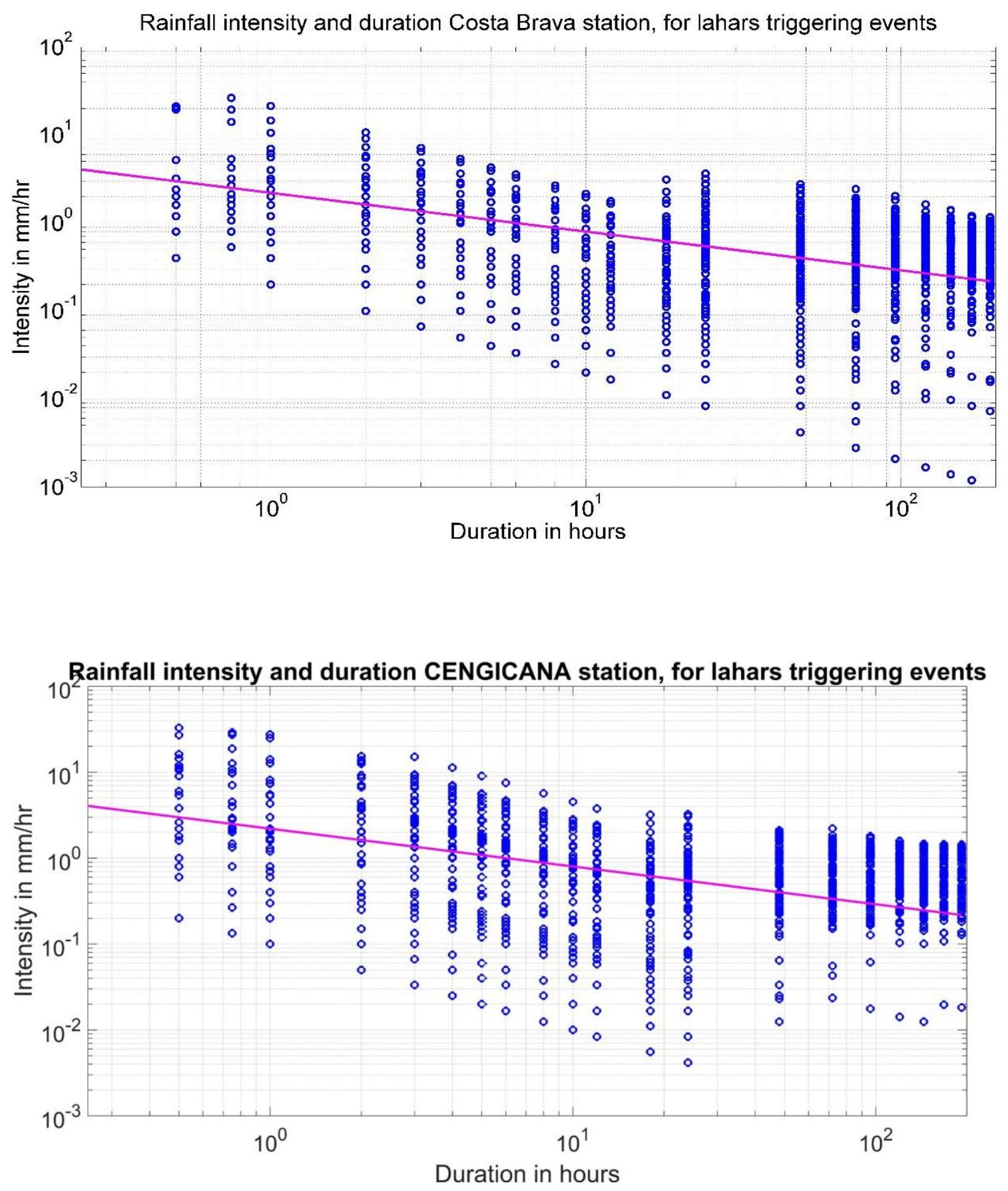

Figure 4.5. Rainfall intensity and duration plots (blue circles) corresponding to the lahars reported in the INSIVUMEH database for rainfall recorded at different stations. Also included is the threshold (magenta line) for debris flows and landslides given by Guzzetti et al. (2008). 
The linear relationship in log-log space previously described seems be more clearly established for rainfall durations of less than 48 to 72 hours, with a large number of cases (many bluecircles) exceeding the linear trend bounding the lower limit. However, for longer durations (> $72 \mathrm{hrs}$.) the number of events (blue circles) for the lower intensities seems to be less common (i. e. less pointdensities at lower intensities and longer durations), despite some lahar events still associated with very low intensities at those durations.

It is possible to see, especially in the OVFUEGO I station, that the rainfall intensity values from 72 to 196 hours interval, are characterized by higher precipitation values compared to the short-term period (from 15 minutes to 48 hours) before the occurrence of the lahar.

For periods of more than 72 hours itis uncommon to have low precipitation values (< $0.05 \mathrm{~mm}$ for El Platanar, $<0.1 \mathrm{~mm}$ for Costa Brava, $<0.2 \mathrm{~mm}$ for the OVFUEGO I), while for the short-term period the precipitation values range from low to high values.

This might suggest that, if the long-term period hasn't experienced a high enough rainfall intensity, the lahar can't be triggered; whereas in the short-term period, regardless of the precipitation value, the event will still occur. Therefore, the long-term precipitation period will have a larger impact on the event than the short-term one.

It is also important to keep in mind that the intensities and durations measures over very long time periods may not be valid representations of continuous rainfall, as usually the rainfall over such extended periods of time corresponds to rainfall events (e. g. rainstorms) of much shorter duration. We have not assessed such an effect in our data.

These results show that for short rainfall durations there is a linear trend between the intensity and duration of the rainfall that bounds the minimum values that will trigger a 
lahar, and such a relation might be different for long duration precipitation, with higher intensities (above the linear trend) being necessary in more cases to trigger the lahars. However, this association is rather weak and will need more work to be confirmed.

2. Most lahars will occur relatively soon after a volcanic eruption.

Lahars often follow explosive eruptions, and this effect can be tracked for longperiods of time after the explosive activity has ended, particularly for large eruptions (e. g. Vallance and Iverson, 2015 and references therein). The timeinterval between explosive eruptions and lahar generation can be analyzed by using the catalog of eruptions compiled by EscobarWolf (2013) and INSIVUMEH (unpublished) for Fuego volcano, and the lahar catalog previously mentioned and finding the times between events in both catalogs.

Figure 4.6 shows a histogram of the times between eruptions and the occurrence of lahars, binned in 10 day periods.

The higher lahar frequency is clearly visible in the second and third class, that means between 10 and 30 days after the last eruption. This would be consistent with the hypothesis that the eruptive activity increases the occurrence of lahars. One mechanism through which this is possible is the availability of new, loose and unstable material deposited by the explosive eruptions and which would become the source of material for the lahars. 


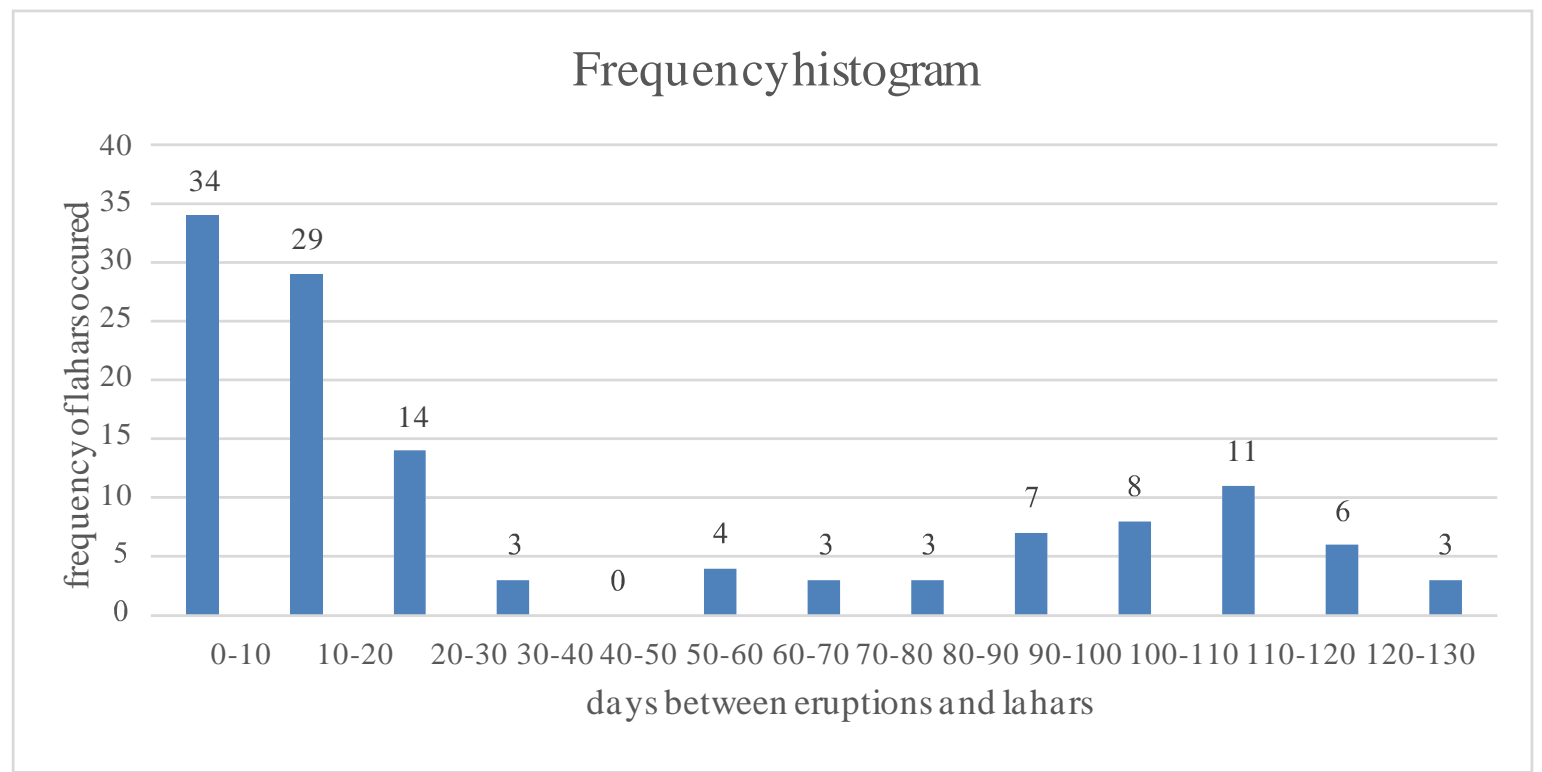

Figure 4.6. Histogram of time intervals between explosive eruptions and the occurrence of lahars at Fuego volcano. Data from Escobar-Wolf (2013) and INSIVUMEH (unpublished). 


\section{Conclusions}

Fuego volcano is a highly active volcano characterized by vigorous volcanic activity; this, together with the intense rainfall events that seasonally affect the area, make its monitoring essential. The continuous monitoring and the study of its historical data allow us to predict which areas could be affected by eruptions and concatenated volcanic hazards in the future. However, the ground monitoring can be challenging for different reasons, like ongoing volcano activity or limited accessibility of the area. Therefore, satellites monitoring not only helps visualizing what is difficult to reach, it can also be used as a tool for improving early warning and forecasting of the volcano activity.

PS images become a significant tool compared to other data sources, not only for its high cadence but also for its resolution. Indeed, the high resolution of PS images allows to map structural and morphologica 1 changes associated with the volcanic activity in detail, making itpossible to analyze a variety of deposits such as lava flows, airfall tephra or lahars.

Thus, analyzing PS images it was possible to detect changes in the sediment coverage from January 2017 to July 2018, but the use of change detection techniques, such as NDVI difference, gives good results only for a certain kind of deposits, such as airfall tephra. In non-vegetated areas, like active barrancas, it is difficult or almost impossible to detect a change in NDVI. This is the case for the lahar deposits, which pose the biggest threat to people livingor recreating along the channels that drain Fuego; and is the reason why the lahars were visually mapped.

As many areas near the crater were affected by factors other than lahars, it was difficult to classify these areas strictly as lahars. In addition, the LAHARZ program was used to calculate the lahar hazard zones in the same areas affected between 2017 and 2018. The visually detected and simulated lahar zones were then compared and verified. 
The approach to lahar detection based on PS image data that was used in this study was very effective for estimating the areas expected to be affected by volcanic eruptions and concatenated hazards, proving relatively precise estimations of volume changes over time.

In contrast, the LAHARZ program approach to calculate the lahar-affected area showed some inconsistencies with the satellite detected data. LAHARZ enables the rapid production of hazard maps after a volcanic eruption based on minimal data for the affected areas but it doesn't give realistic inundation areas.

A more detailed DEM, laterally constrained channel gorges and specific coefficients for each volcano's characteristics could show simulations more comparable to the mapped or field observations.

By analyzing the rainfall dataset, itwas possible to assert that: the lahars need a minimum value of rainfall intensity to be triggered (especially for the long-term period) lahars are more likely to occur soon after eruptions and decrease in likelihood each day thereafter, and for the more time there is between the eruption and the lahar, the higher the critical rainfall intensity that is needed.

The rainfall statistical analysis covers only a two years period of time, from January 2016 to November 2018. For thisreason, all the mechanisms showed cannot becompletely clear and accurate.

Therefore, analyzing these satellite images, it is possible to see that, even though the major events occurred after the $3^{\text {rd } J u n e ~} 2018$ eruption, the changes were already slowly happening even during 2017, especially in the Barrancas Pantaleon, Ceniza and Achiguate.

This methodology could be applied to any other active volcano, but a more detailed data set would be beneficial. However, comparing the volcano activity and response through 
time can help to assess the future hazard potential at Fuego, since many of the eruptive phenomena may have similar mechanisms, despite the differences in scale between them. 


\section{References}

Aldeghi, A., Carn, S., Escobar-Wolf, R., \& Groppelli, G. (2019). Volcano Monitoring from Space Using High-Cadence Planet CubeSat Images Applied to Fuego Volcano, Guatemala. Remote Sensing, 11(18), 2151.

Arnous, M. O., \& Green, D. R. (2010). GIS and remote sensing as tools for conducting geo-hazards risk assessment along Gulf of Aqaba coastal zone, Egypt. Journal of Coastal Conservation, 15(4), 457-475.

Basset, T., 1996, Histoire éruptive et évaluations des aléas du volcan Acatenango Guatemala: PhD thesis, University of Geneva, 240 p.

Baumann, V., Bonadonna, C., Cuomo, S., Moscariello, M., \& Manzella, I. (2018). Slope stability models for rainfall-induced lahars during long-lasting eruptions. Journal of Volcanology and Geothermal Research, 359, 78-94.

Bolge, L. L., Carr, M. J., Milidakis, K. I., Lindsay, F. N., \& Feigenson, M. D. (2009). Correlating geochemistry, tectonics, and volcanic volume along the Central American volcanic front. Geochemistry, Geophysics, Geosystems, 10(12).

Cameron, B. I., Walker, J. A., Carr, M. J., Patino, L. C., Matıas, O., \& Feigenson, M. D. (2003). Flux versus decompression melting at stratovolcanoes in southeastern Guatemala. Journal of Volcanology and Geothermal Research, 119(1-4), 21-50.

Cando-Jácome, M., \& Martínez-Graña, A. (2019). Determination of Primary and Secondary Lahar Flow Paths of the Fuego Volcano (Guatemala) Using Morphometric Parameters. Remote Sensing, 11(6), 727. 
Carr, M., Patino, L., \& Feigenson, M. (2007). Chapter 22: Petrology and geochemistry of lavas. Buntschuh Central America-Geology, Resources and Hazards, 2, 565-590.

Chesner, C. A., \& Rose, W. I. (1984). Geochemistry and evolution of the Fuego volcanic complex. Journal of Volcanology and Geothermal Research, 21,25-44.

Davies, D. K., Quearry, M. W., \& Bonis, S. B. (1978). Glowing avlanches from the 1974 eruption of the volcano Fuego, Guatemala. Geological Society of America Bulletin, 89, 369-384.

Escobar Wolf, Rüdiger P., "Volcanic processes and human exposure as elements to build a risk model for Volcan de Fuego, Guatemala", Dissertation, Michigan Technological University, 2013. http://digitalc ommons.mtu.edu/etds/638

Gazel, E., Hoernle, K., Carr, M. J., Herzberg, C., Saginor, I., Van den Bogaard, P., ... \& Swisher III, C. (2011). Plume-subduction interaction in southern Central America: Mantle upwelling and slab melting. Lithos, 121(1-4), 117-134.

Joyce, K. E., Belliss, S. E., Samsonov, S. V., McNeill, S. J., \& Glassey, P. J. (2009). A review of the status of satellite remote sensing and image processing techniques for mapping natural hazards and disasters. Progress in Physical Geography: Earth and Environment, 33(2), 183-207.

Kuenzi, W. D., Horst, O. H., \& McGehee, R. V. (1979). Effect of volcanic activity on fluvial-deltaic sedimentation in a modern arc-trench gap, southwestern Guatemala. Geological Society of America Bulletin, 90(9).

Iverson, R. M., Schilling, S. P., \& Vallance, J. W. (1998). Objective delineation of laharinundation hazard zones. Geological Society of America Bulletin, 110(8), 972-984. 
Lyons, J. J., Waite, G. P., Rose, W. I., \& Chigna, G. (2009). Patterns in open vent, strombolian behavior at Fuego volcano, Guatemala, 2005-2007. Bulletin of Volcanology, $72(1), 1-15$.

Manea, V. C., Manea, M., \& Ferrari, L. (2013). A geodynamical perspective on the subduction of Cocos and Rivera plates beneath Mexico and Central America.

Tectonophysics, 609, 56-81.

Martin, D. P., \& Rose, W. I. (1981). Behavioral patterns at Fuego volcano, Guatemala. Journal of Volcanology and Geothermal Research, 10, 67-81.

Planet Team (2017). Planet Application Program Interface: In Space for Life on Earth. San Francisco, CA. https://api.planet.com.

Saginor, I., E. Gazel, C. Condie, and M. J. Carr (2013), Evolution of geochemical variations along the Central American volcanic front, Geochem. Geophys. Geosyst., 14, doi:10.1002/ggge.20259.

Smithsonian Institution. (2019). Recent bulletin report. Bulletin of the Global Volcanism Program.

Tadono, T., Ishida, H., Oda, F., Naito, S., Minakawa, K., \& Iwamoto, H. (2014). Precise global DEM generation by ALOS PRISM. ISPRS Annals of the Photogrammetry, Remote Sensing and Spatial Information Sciences, 2(4), 71.

Vallance, J. W., Schilling S. P., Matías O., Rose W. I., \& Howell M. M. (2001). Volcano hazards at Fuego and Acatenango, Guatemala. U.S. Geolog. Surv. Open-File Rep., 01431, USGS/Cascades Volcano Obs., Vancouver, Wash. 38 
Vallance, J. W., \& Iverson, R. M. (2015). Lahars and their deposits. In The Encyclopedia of Volcanoes (pp. 649-664). Academic Press.

Waite, G. P., Nadeau, P. A., \& Lyons, J. J. (2013). Variability in eruption style and associated very long period events at Fuego volcano, Guatemala. Journal of Geophysical Research: Solid Earth, 118(4), 1526-1533.

Webley P. W., Wooster M. J., Strauch W., Saballos J. A., Dill K., Stephenson P., Stephenson J., Escobar Wolf R. \& O. Matias (2008). Experiences from near-real-time satellite-based volcano monitoring in Central America: case studies at Fuego, Guatemala. International Journal of Remote Sensing, 29:22, 6621-6646

World Bank. 2018. Concatenated Volcanic Hazards Fuego Volcano crisis, June 3rd 2018. 


\section{Appendix A}
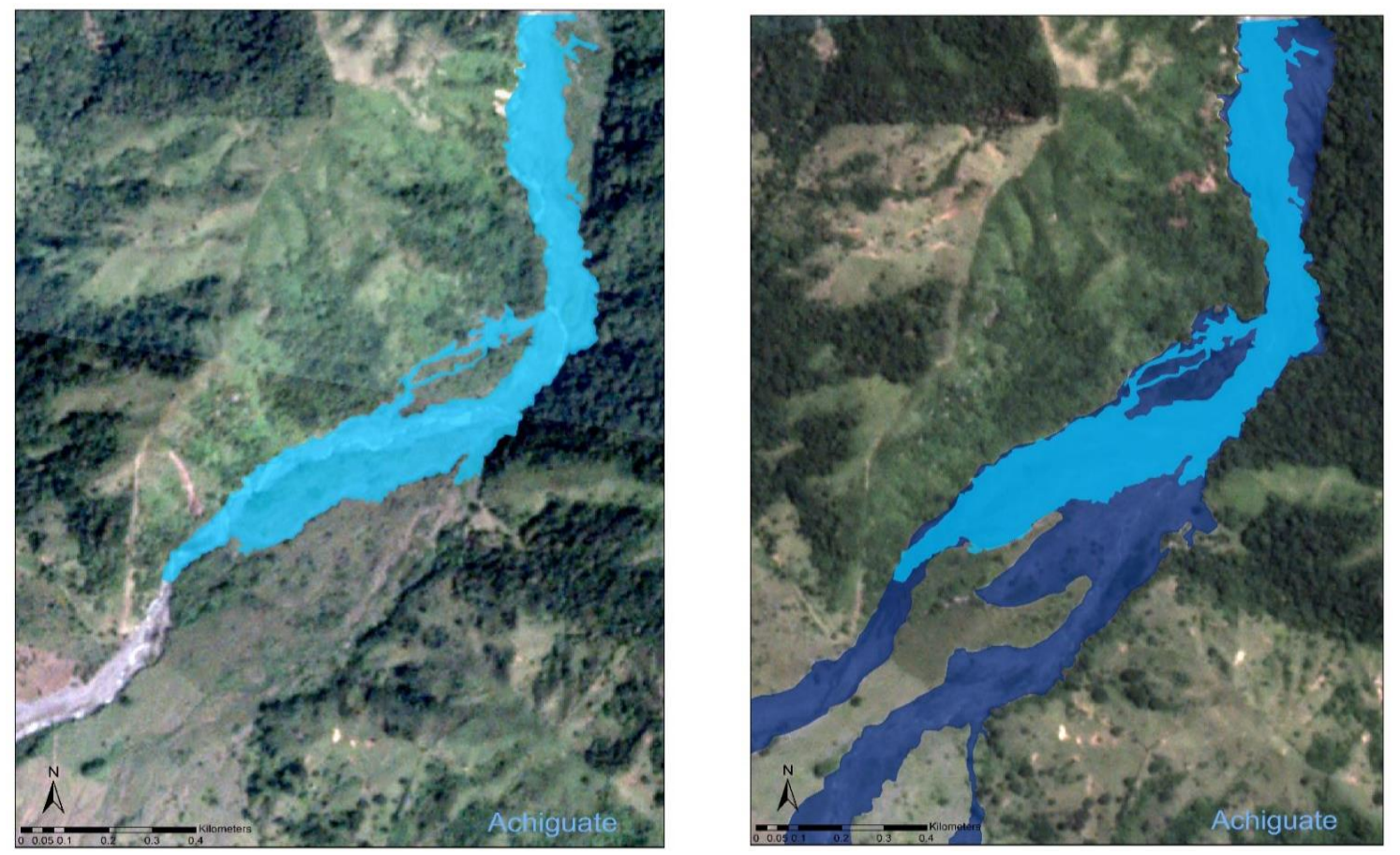

Figure 6.1. Comparison between satellite based mapping of lahar deposits from the July 2017 lahar activity (left panel) and July 2018 lahar activity (right panel) in the Achiguate channel.
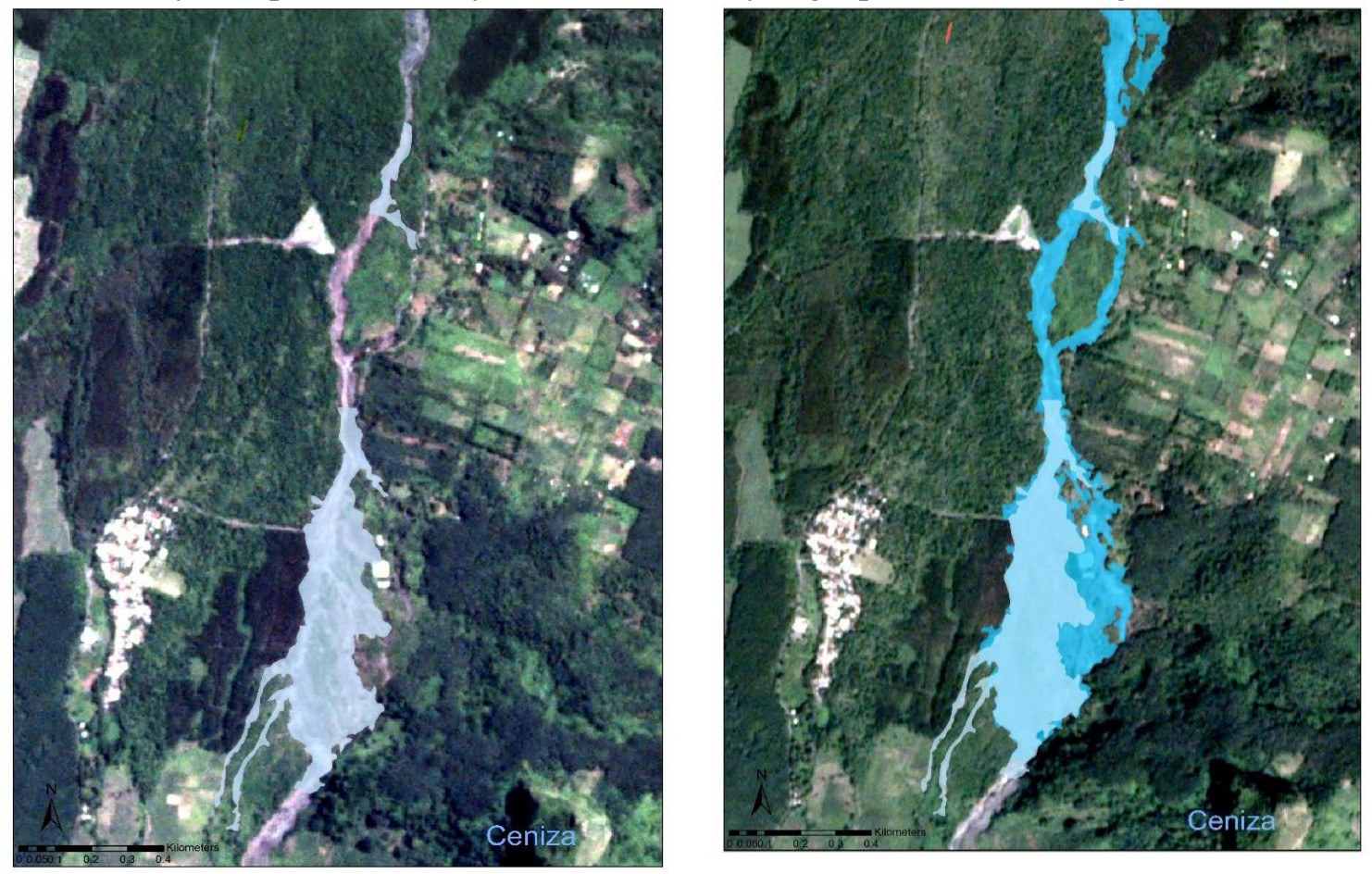

Figure 6.2. Comparison between satellite based mapping of lahar deposits from the July 2017 lahar activity (left panel) and October 2017 lahar activity (right panel) in the Ceniza channel. 

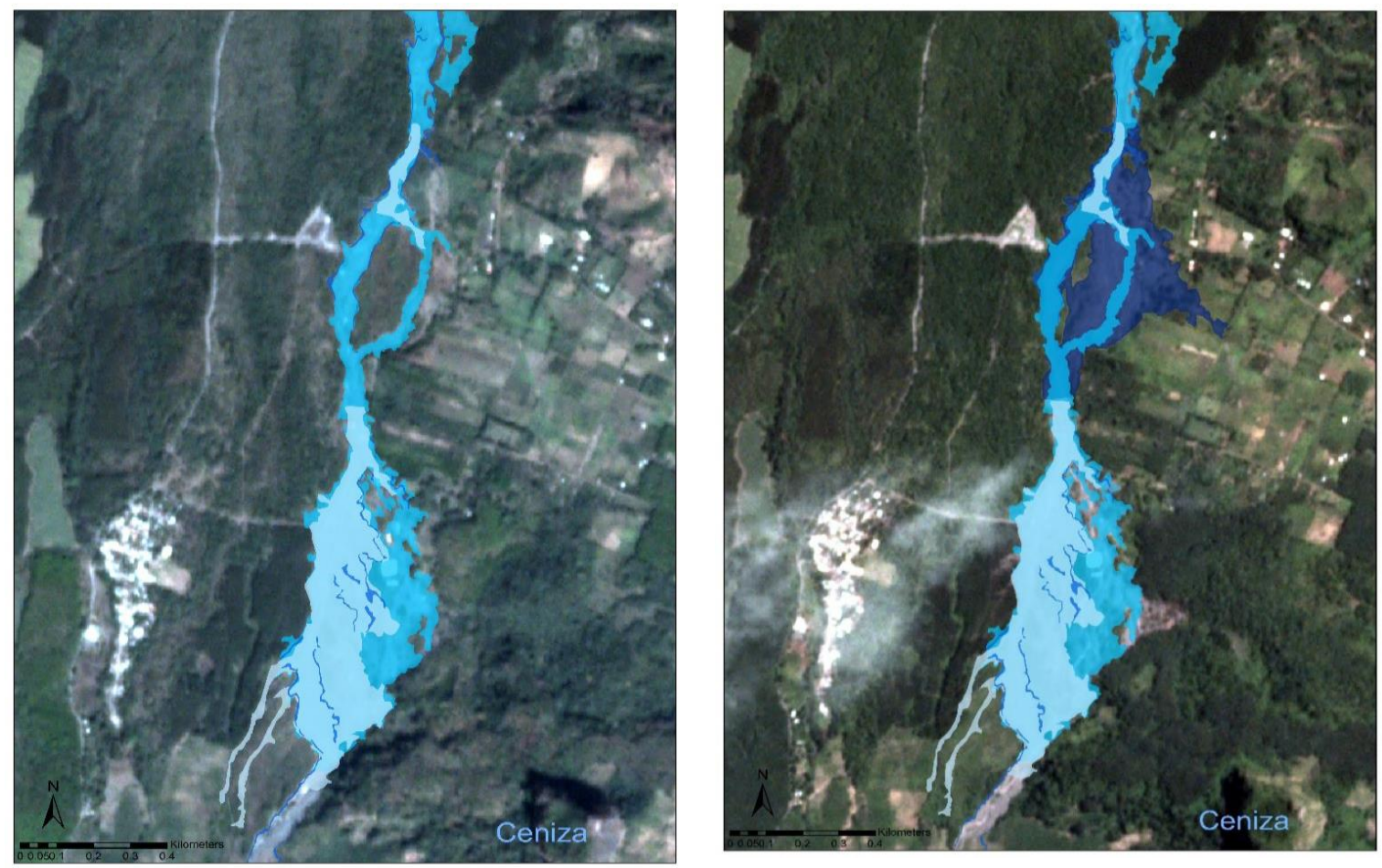

Figure 6.5. Comparison between satellite based mapping of lahar deposits from the January 2018 lahar activity (left panel) and July 2018 lahar activity (right panel) in the Ceniza channel.
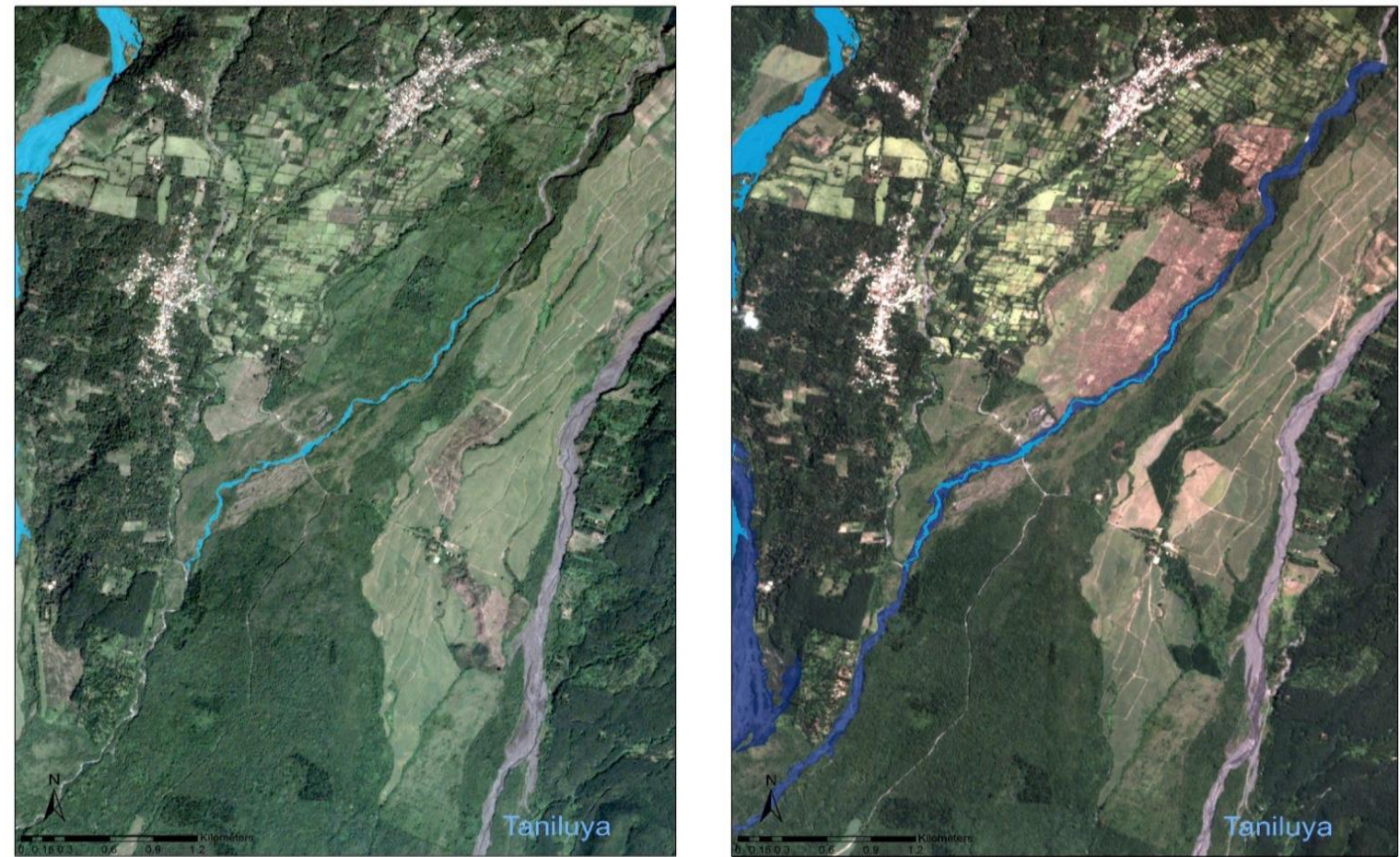

Figure 6.4. Comparison between satellite based mapping of lahar deposits from the October 2017 lahar activity (left panel) and July 2018 lahar activity (right panel) in the Taniluya channel. 

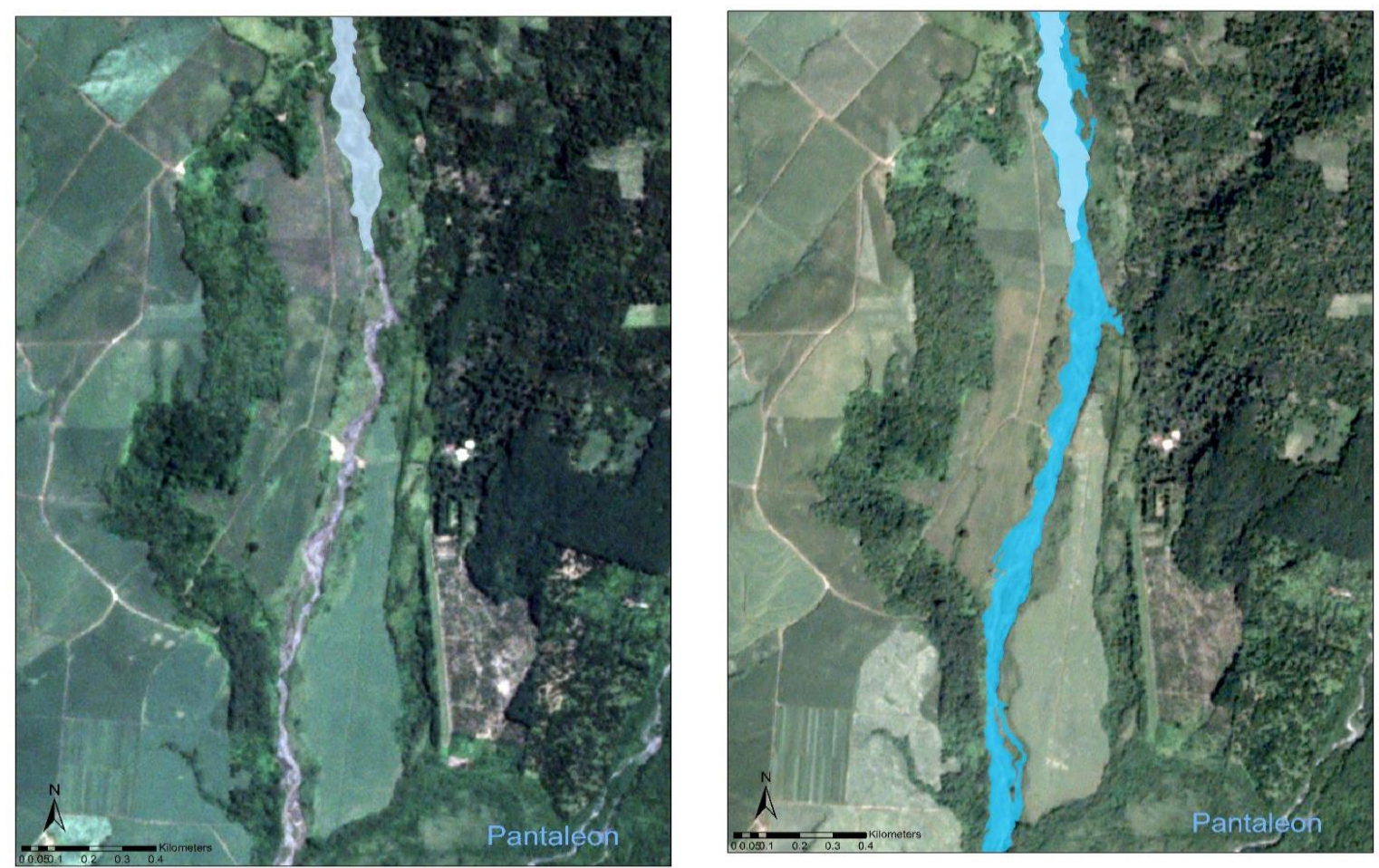

Figure 6.5. Comparison between satellite based mapping of lahar deposits from the July 2017 lahar activity (left panel) and October 2017 lahar activity (right panel) in the Pantaleonchannel.
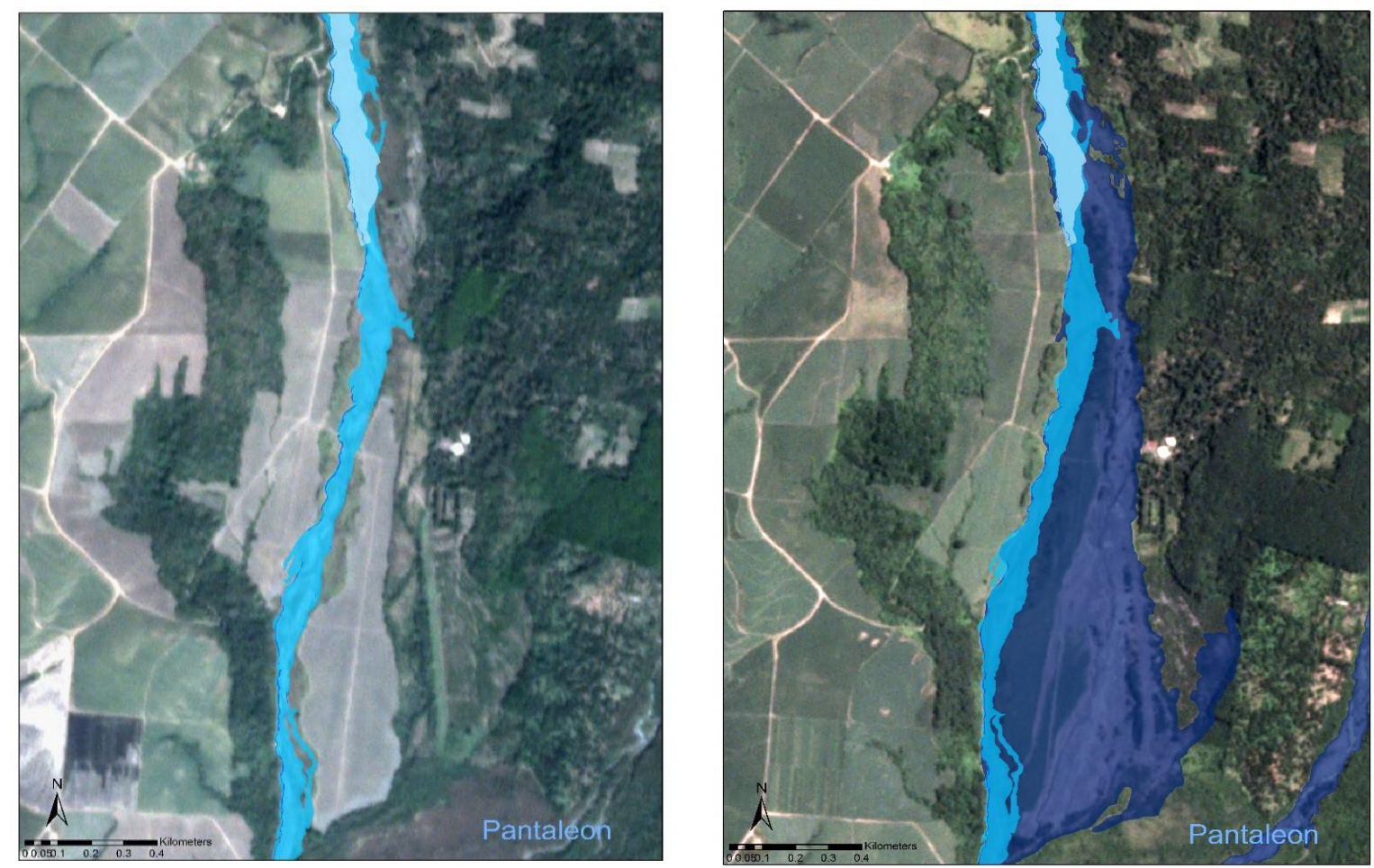

Figure 6.6. Comparison between satellite based mapping of lahar deposits from the July 2017 lahar activity (left panel) and October 2017 lahar activity (right panel) in the Pantaleon channel. 

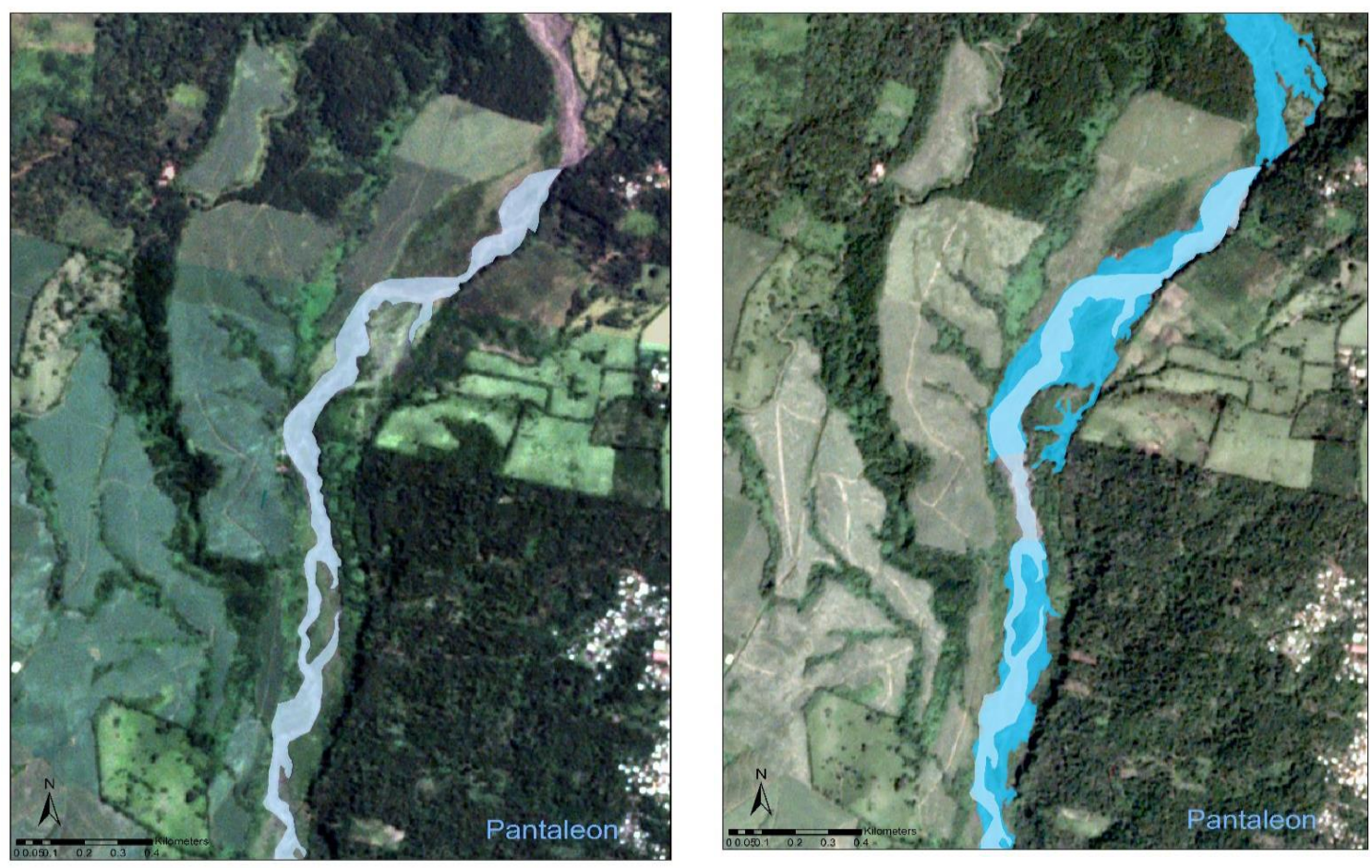

Figure 6.7. Comparison between satellite based mapping of lahar deposits from the July 2017 lahar activity (left panel) and October 2017 lahar activity (right panel) in the Pantaleon channel.
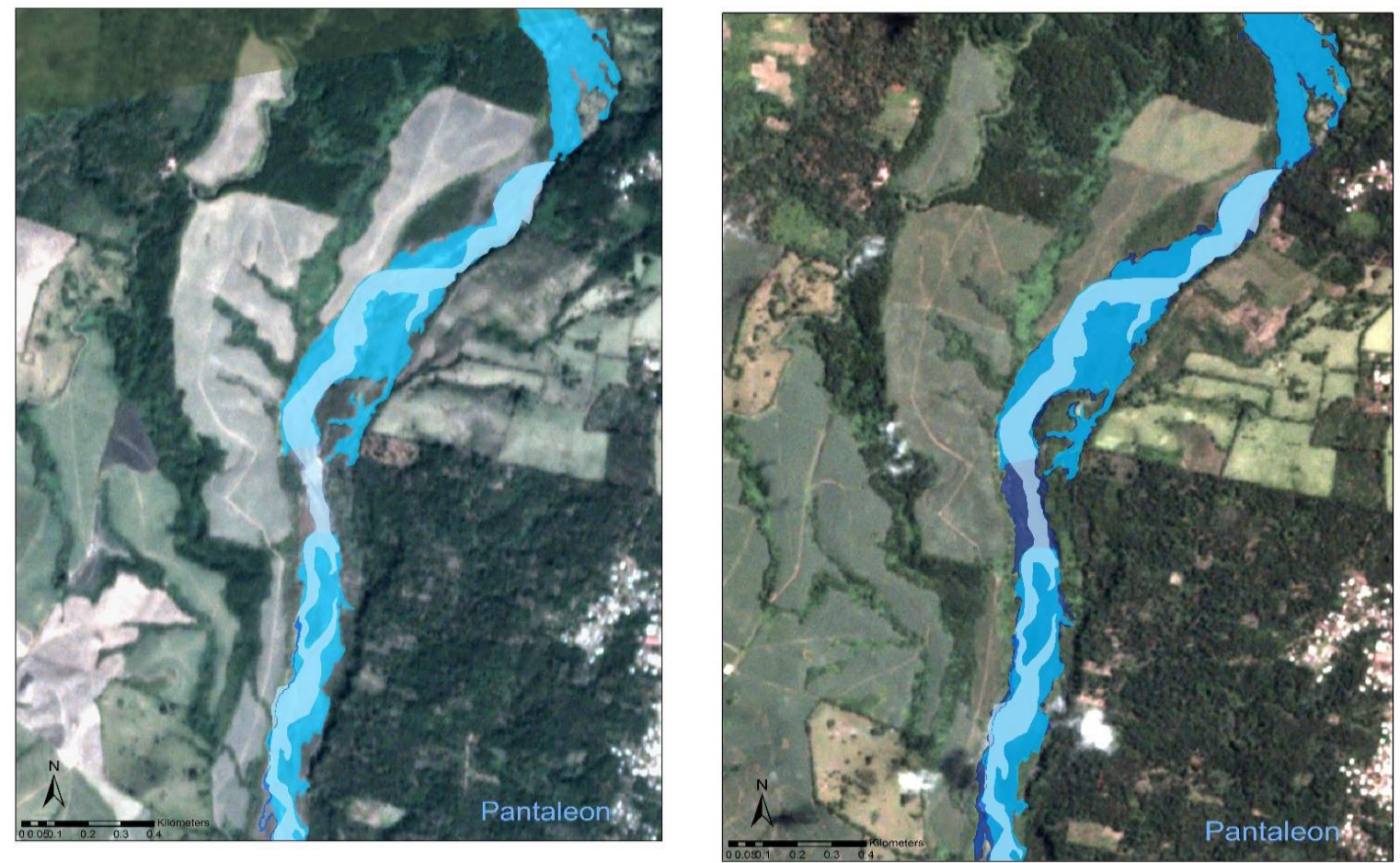

Figure 6.1. Comparison between satellite based mapping of lahar deposits from the January 2018 lahar activity (left panel) and July 2018 lahar activity (right panel) in the Pantaleon channel. 


\section{Appendix B}

This appendix shows the difference between the visually mapped lahars and the LAHARZ models. The mapped and simulated polygons in red cover seven months period (January 2017 - July 2017), the yellow ones a four months period (July 2017 October 2017).
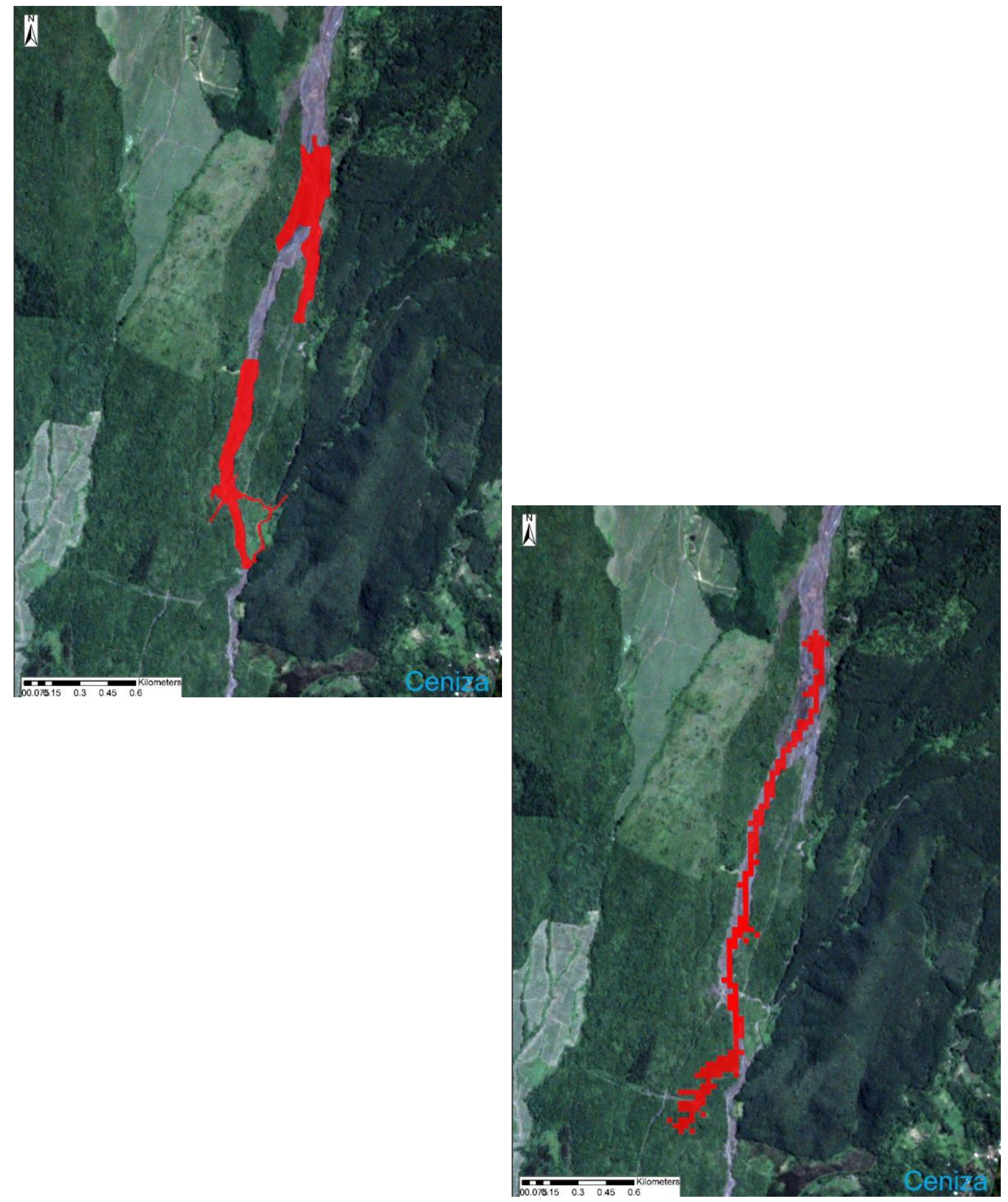

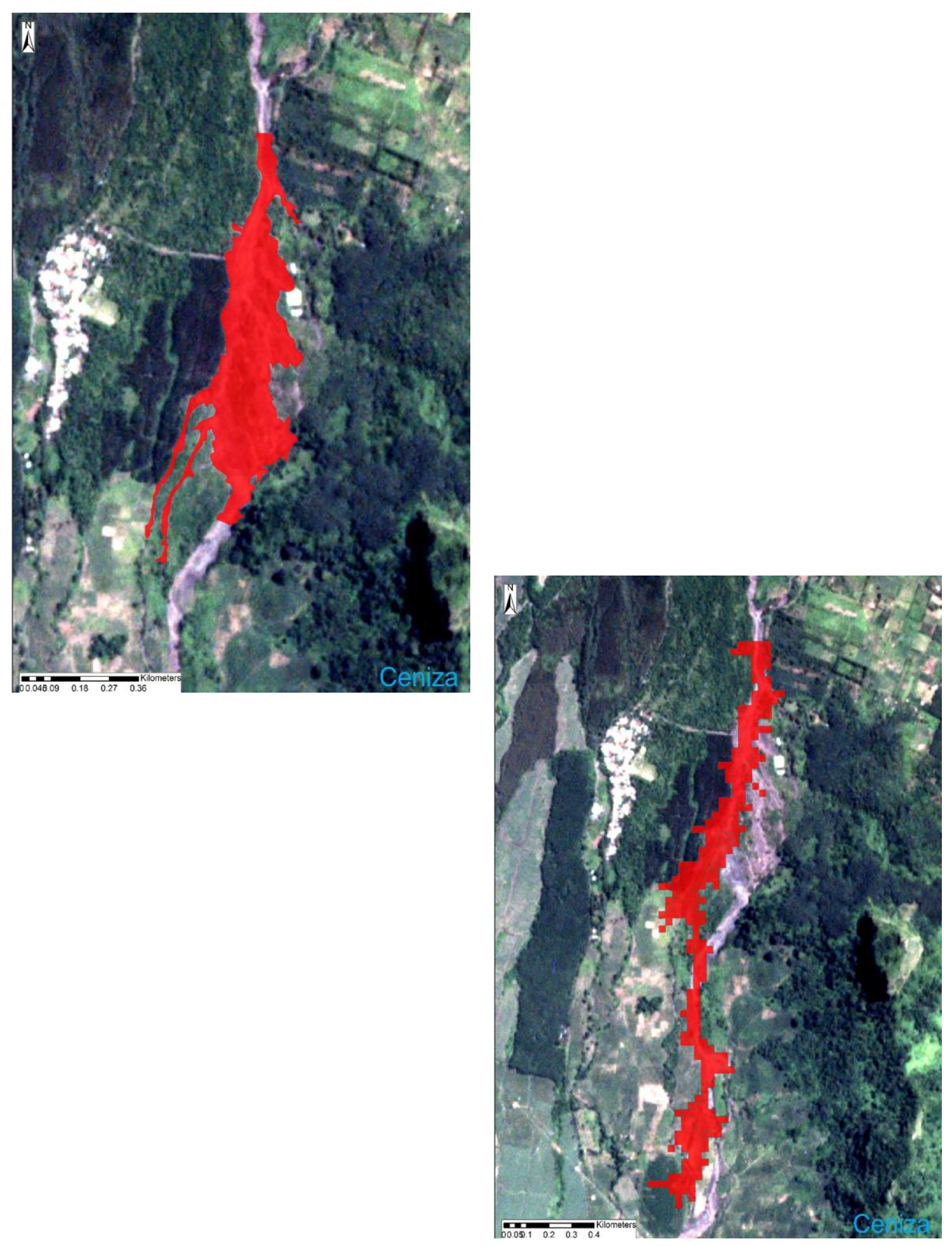

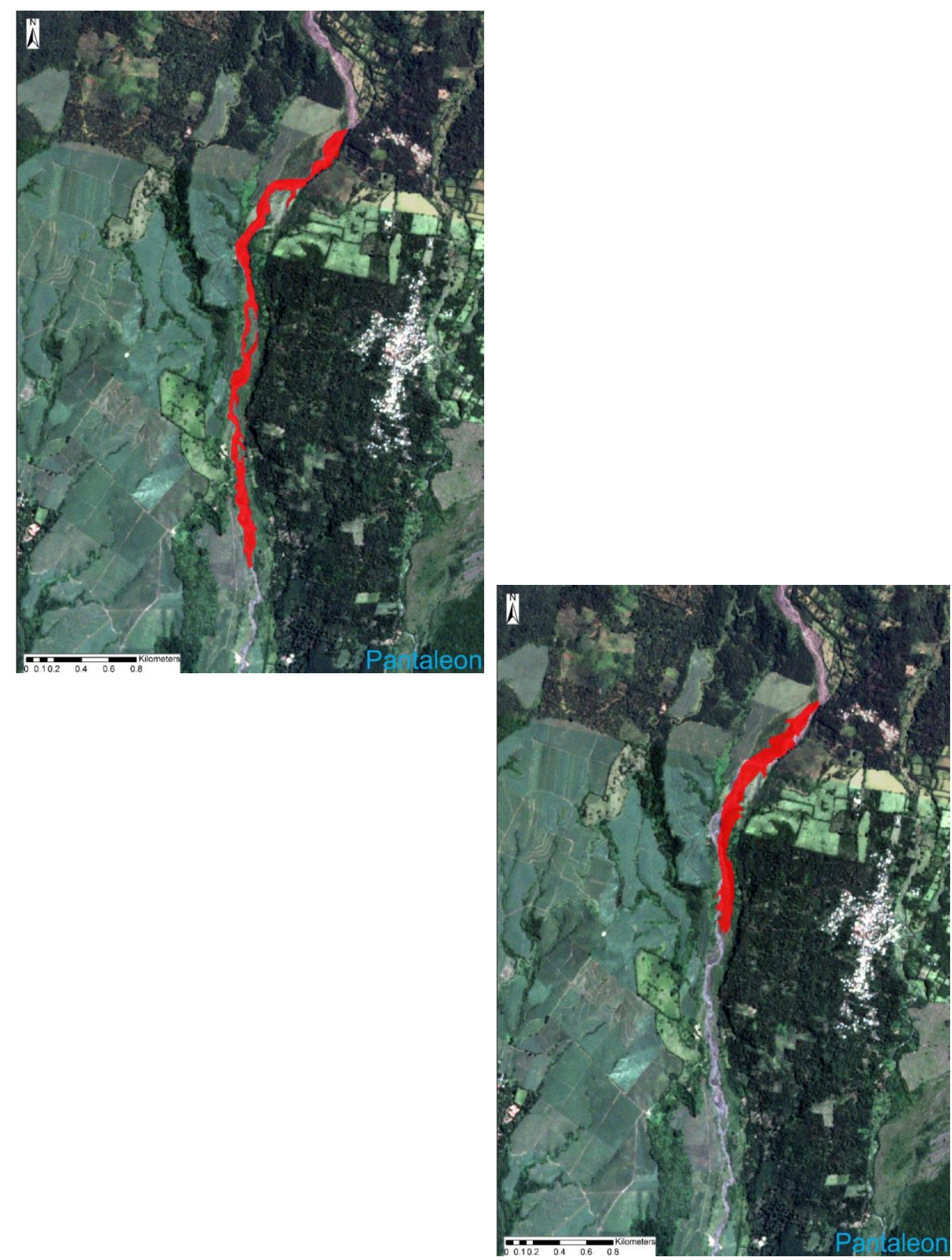

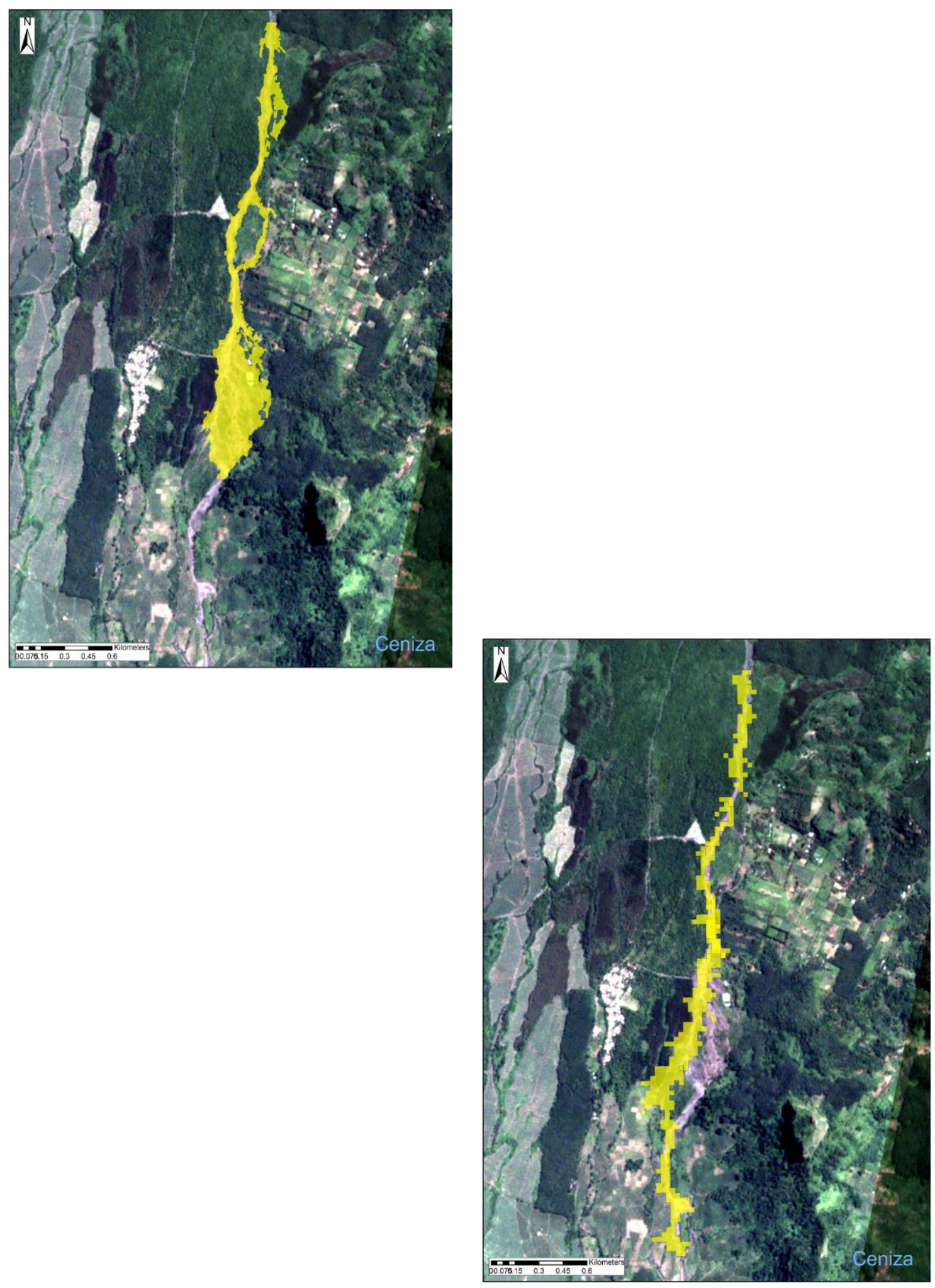

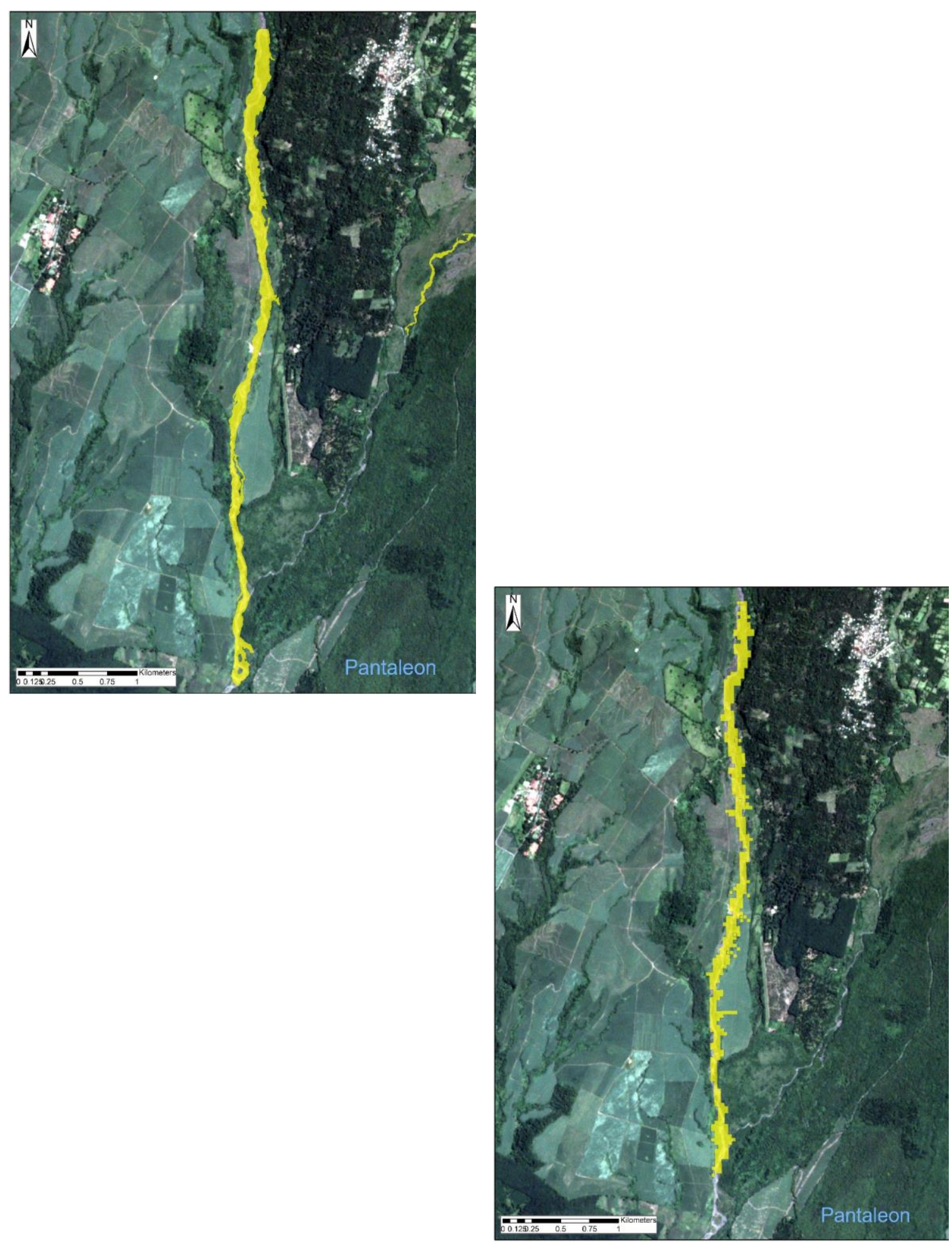

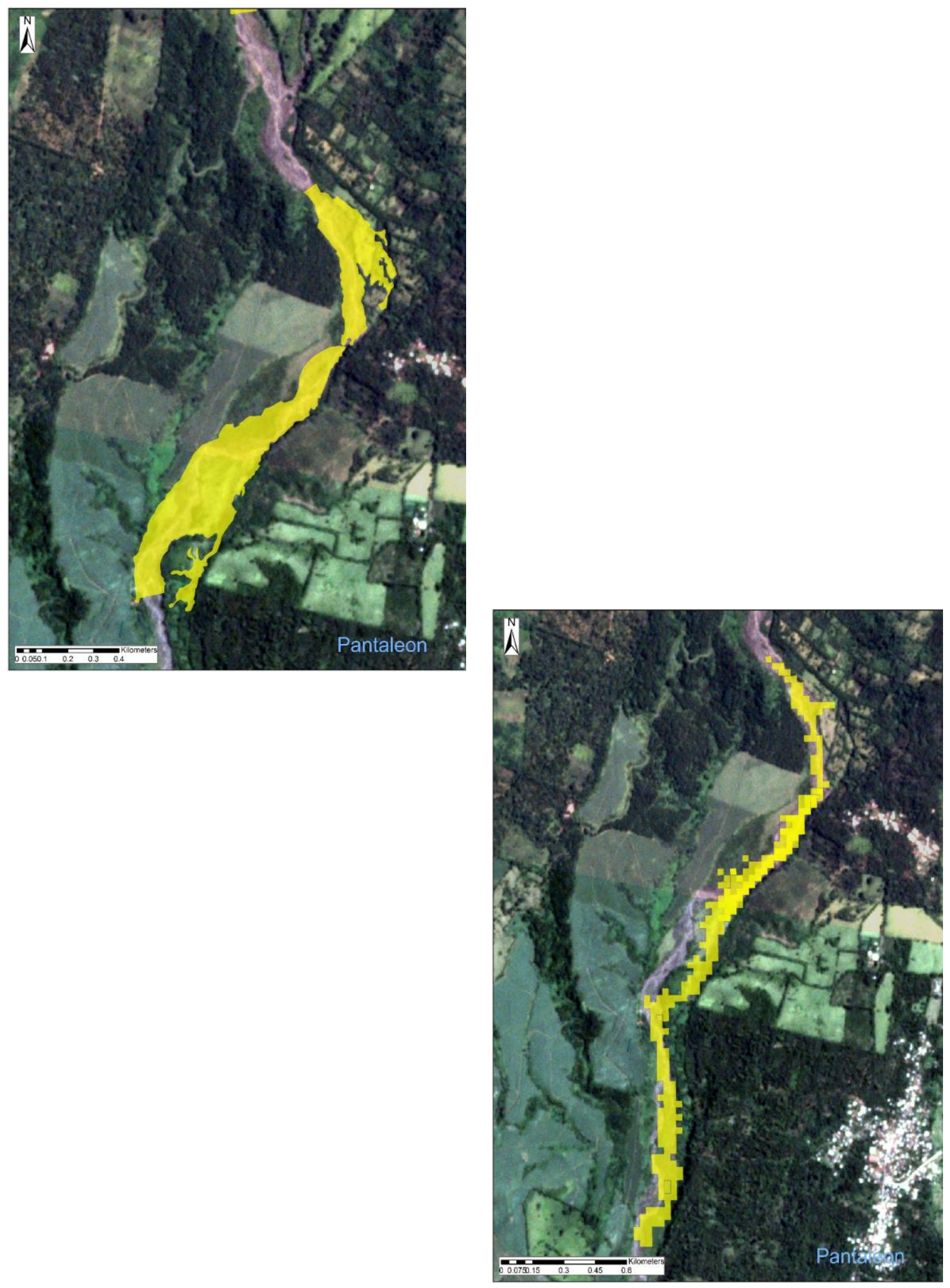

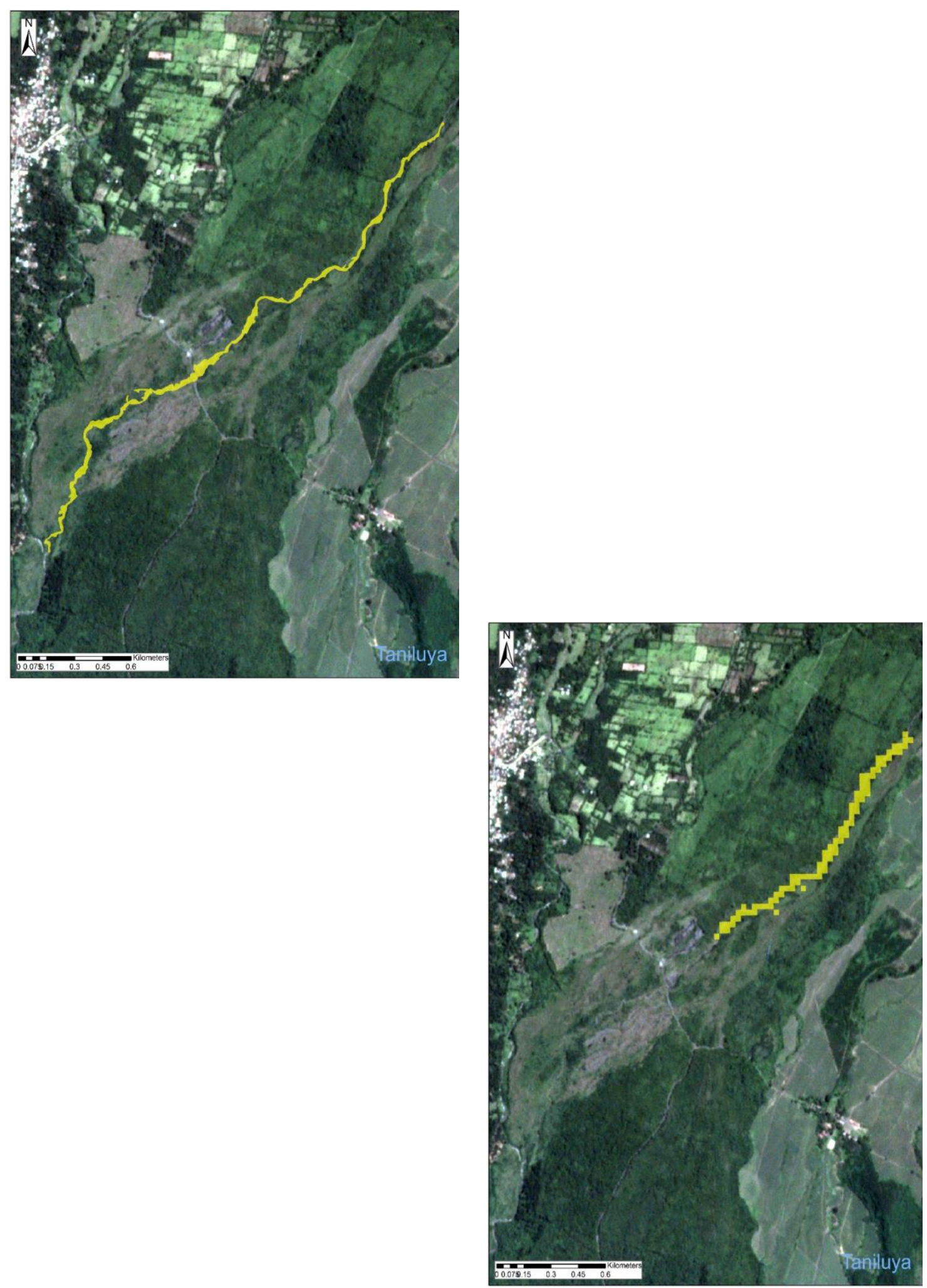

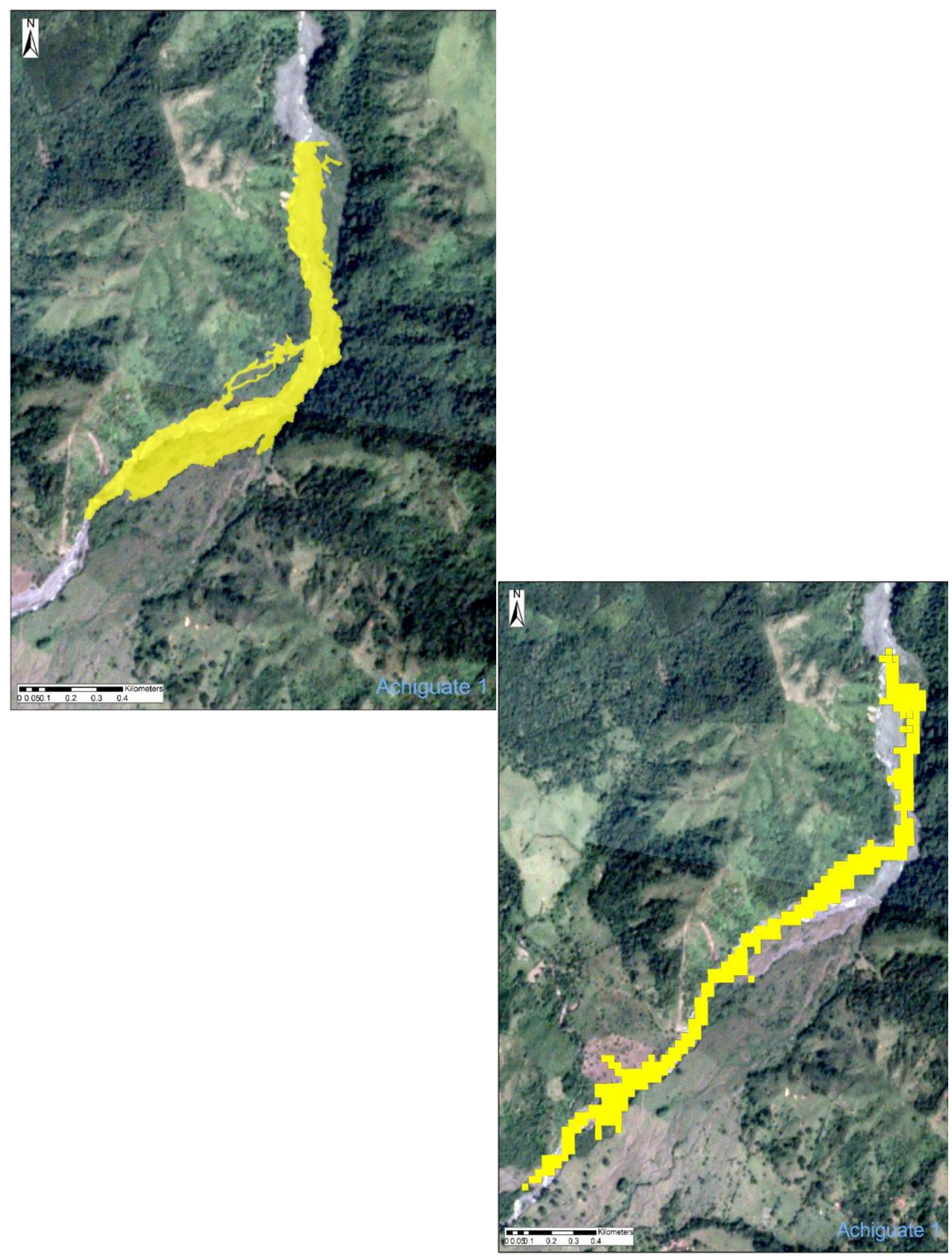